\title{
From DNA Copy Number Gains and Tumor Dependencies to Novel Therapeutic Targets for High-Risk Neuroblastoma
}

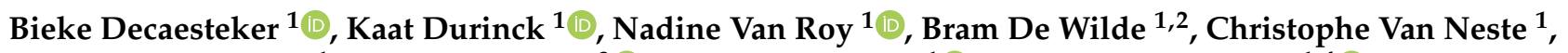 \\ Stéphane Van Haver ${ }^{1}$, Stephen Roberts ${ }^{3}\left(\mathbb{D}\right.$, Katleen De Preter ${ }^{1}\left(\mathbb{D}\right.$, Vanessa Vermeirssen ${ }^{1,4} 4^{(D)}$ \\ and Frank Speleman $1, * \mathbb{D}$ \\ 1 Department for Biomolecular Medicine, Ghent University, Medical Research Building (MRB1), \\ Corneel Heymanslaan 10, B-9000 Ghent, Belgium; Bieke.Decaesteker@ugent.be (B.D.); \\ Kaat.durinck@ugent.be (K.D.); Nadine.vanroy@ugent.be (N.V.R.); Bram.DeWilde@UGent.be (B.D.W.); \\ Christophe.vanneste@ugent.be (C.V.N.); Stephane.VanHaver@ugent.be (S.V.H.); \\ Katleen.DePreter@ugent.be (K.D.P.); Vanessa.Vermeirssen@ugent.be (V.V.) \\ 2 Department of Internal Medicine and Pediatrics, Ghent University Hospital, Corneel Heymanslaan 10, \\ B-9000 Ghent, Belgium \\ 3 Department of Pediatrics, Memorial Sloan Kettering Cancer Center, New York, NY 10065, USA; \\ robertss@mskcc.org \\ 4 Department of Biomedical Molecular Biology, Ghent University, Technologiepark 71, \\ B-9052 Zwijnaarde, Belgium \\ * Correspondence: franki.speleman@ugent.be
}

Citation: Decaesteker, B.; Durinck, K.; Van Roy, N.; De Wilde, B.; Van Neste, C.; Van Haver, S.; Roberts, S.; De Preter, K.; Vermeirssen, V.; Speleman, F. From DNA Copy Number Gains and Tumor

Dependencies to Novel Therapeutic Targets for High-Risk Neuroblastoma. J. Pers. Med. 2021, 11, 1286. https:// doi.org/10.3390/jpm11121286

Academic Editors: Walter Kolch and Cormac Owens

Received: 11 October 2021

Accepted: 20 November 2021

Published: 3 December 2021

Publisher's Note: MDPI stays neutral with regard to jurisdictional claims in published maps and institutional affiliations.

Copyright: (c) 2021 by the authors. Licensee MDPI, Basel, Switzerland. This article is an open access article distributed under the terms and conditions of the Creative Commons Attribution (CC BY) license (https:// creativecommons.org/licenses/by/ $4.0 /)$.

\begin{abstract}
Neuroblastoma is a pediatric tumor arising from the sympatho-adrenal lineage and a worldwide leading cause of childhood cancer-related deaths. About half of high-risk patients die from the disease while survivors suffer from multiple therapy-related side-effects. While neuroblastomas present with a low mutational burden, focal and large segmental DNA copy number aberrations are highly recurrent and associated with poor survival. It can be assumed that the affected chromosomal regions contain critical genes implicated in neuroblastoma biology and behavior. More specifically, evidence has emerged that several of these genes are implicated in tumor dependencies thus potentially providing novel therapeutic entry points. In this review, we briefly review the current status of recurrent DNA copy number aberrations in neuroblastoma and provide an overview of the genes affected by these genomic variants for which a direct role in neuroblastoma has been established. Several of these genes are implicated in networks that positively regulate MYCN expression or stability as well as cell cycle control and apoptosis. Finally, we summarize alternative approaches to identify and prioritize candidate copy-number driven dependency genes for neuroblastoma offering novel therapeutic opportunities.
\end{abstract}

Keywords: neuroblastoma; DNA copy number gains; $M Y C N$; dependency; drug targets

\section{Introduction}

Neuroblastoma (NB) is a pediatric tumor arising from the sympathetic neuronal lineage with a remarkably variable clinical presentation. The majority of children diagnosed with NB below the age of 18 months present with low or intermediate risk disease and have an excellent prognosis (INRGSS stages L1,L2 and MS with favourable genomic features) [1-3]. Older children with NB typically present with high-risk disease and require multi-modal intensive therapy. Despite this aggressive treatment, half of these patients will succumb to their disease. Those that do survive often have long-lasting negative health effects. A special type of NB occurs at a very young age, but with a peculiar metastatic pattern including skin, liver, and bone marrow metastases (Stage MS) but which regresses or differentiates with minimal therapeutic intervention [3].

After decades of research insights are growing into the underlying genetic features of the complex heterogeneous clinical behavior of this enigmatic tumor. Amplification 
of the MYCN oncogene was one of the first discovered genetic alterations in NB [4,5]. It was rapidly recognized as an important prognostic indicator and critical determinant for therapeutic patient stratification. Additionally, DNA content measurements revealed near triploid DNA content in stage L1/2 and MS cases [6]. Following these early pioneering observations, additional chromosomal analyses, loss-of-heterozygosity studies, comparative genomic hybridization, DNA arrays and most recently DNA sequencing have provided a comprehensive view on NB genomes. The mutational landscape has been shown to be relatively silent with $A L K$ mutations being the only substantially mutated target in almost $10 \%$ of cases at diagnosis [7-11], while in relapsed cases increase of RAS/MAPK pathway mutations was noted (including $A L K$ mutations) [12-14]. In older NB patients (adolescents and young adults with a more indolent or chronic form of NB), roughly $30 \%$ of cases present with ATRX deletions (indels) or loss-of function missense mutations and in-frame fusions in rare cases [15-18]. TERT rearrangements and enhancer hijacking is found in $25 \%$ of NB patients $[17,18]$.

In contrast to the overall paucity of mutations, low and high-risk NB presents with highly recurrent whole chromosome or segmental imbalances and focal copy number aberrations (CNAs) respectively $[19,20]$. This remarkably consistent pattern of chromosomal imbalances has led to the suggestion that dosage effects of genes residing on the affected chromosomal regions contribute to tumor biology. This is obvious for the prototypical MYCN oncogene which is amplified in 30\% of the high-risk NB cases and which acts as a strong dependency factor [21]. In addition to this frequent amplification event, additional genes have been identified (described in more detail in this review) that are involved in rare high-level amplifications or focal gains and which were subsequently shown to contribute to tumor behavior and dependency. Interestingly, many of these rare amplicons affect loci that map to the highly recurrent common large segmental gains such as $2 p$ - and 17q gain suggesting that these rare focal gains and amplifications may serve as "smoking guns" to identify novel and potentially druggable NB genes.

In this review, we will first give a short historical overview on the detection of DNA copy number abnormalities in NB. Next, we summarize and discuss the currently identified genes with an established role in NB biology which are located on regions affected by gains and/or amplifications and address their role in NB tumor dependency potential for druggable interventions. While progress has been made in deciphering which copy number affected genes could potentially contribute to NB tumor behavior, several important questions remain unanswered. First, exactly how does a single extra copy of a large chromosomal region which encompasses dozens or more gene loci impact on the NB tumor phenotype? Second, are there any genes that enhance the effect of dosage genes through additive or epistatic effects? Third, do large DNA copy number imbalances act as drivers of early tumor formation, or do they predominantly contribute to tumor maintenance and dependency at a later stage, or both? At least for the first question, we have additional evidence that DNA copy number gains are unlikely to be innocent bystanders. Indeed, in MYCN driven mouse tumors we also observed large segmental chromosome gains for a region of mouse chromosome 11 which is syntenic to human chromosome 17 [22]. Also, recent whole genome sequencing data indicate that the common imbalances are early events preceding the occurrence of mutations [23]. However, this only provides partial insight into how these copy number gains affect tumor behavior; to answer these questions new experimental approaches are needed. The last section of this review proposes a number of non-exhaustive experimental and analytical strategies that are currently emerging and may allow us to answer these questions. Given the paucity of options for targeted therapy based on mutations only, a better understanding of the critically involved copy number driven genes and their putative epistatic interactions may provide important insights for testing novel therapeutic strategies. 


\section{Recurrent Focal and Large Segmental DNA Copy Number Alterations in NB}

In addition to the existence of double minutes and homogeneously staining regions resulting from high level MYCN amplification, the first cytogenetic studies also detected recurrent large distal $1 \mathrm{p}$ deletions [24]. Chromosome $1 \mathrm{p}$ deletions are usually associated with $M Y C N$ amplification but also occur in MYCN non-amplified high-risk NB (Figure 1) [25]. Subsequent loss-of-heterozygosity studies defined a critical 1p36 segment commonly affected by $1 \mathrm{p}$ deletions $[26,27]$ as well as the discovery of additional recurrent deletions affecting $3 \mathrm{p}, 4 \mathrm{p}$ and $11 \mathrm{q}$ [28]. Using comparative genomic hybridization (CGH) and DNA arrays these $11 \mathrm{q}$ deletions were shown to predominantly occur in high-risk MYCN nonamplified NBs [29,30] (Figure 1). These analyses also allowed a comprehensive mapping of gains across the NB genomes [19,31-33]. Whole chromosome imbalances were invariably present in low-risk L1/2 and MS NB while highly recurrent segmental gains mark stage M NBs. The most frequently occurring segmental gain implicated a large distal section of the long arm of chromosome 17 with breakpoints typically distal to 17q21 [34-37] (Figure 1). Other recurrent gains affecting larger chromosome segments involve 1q, 2p, 7q, 11q13.3 and 12q of which some loci are also affected by higher level focal amplification [23]. Of note, the typical deletions and gains of large chromosome arm segments often result from one single unbalanced chromosomal translocation [34].

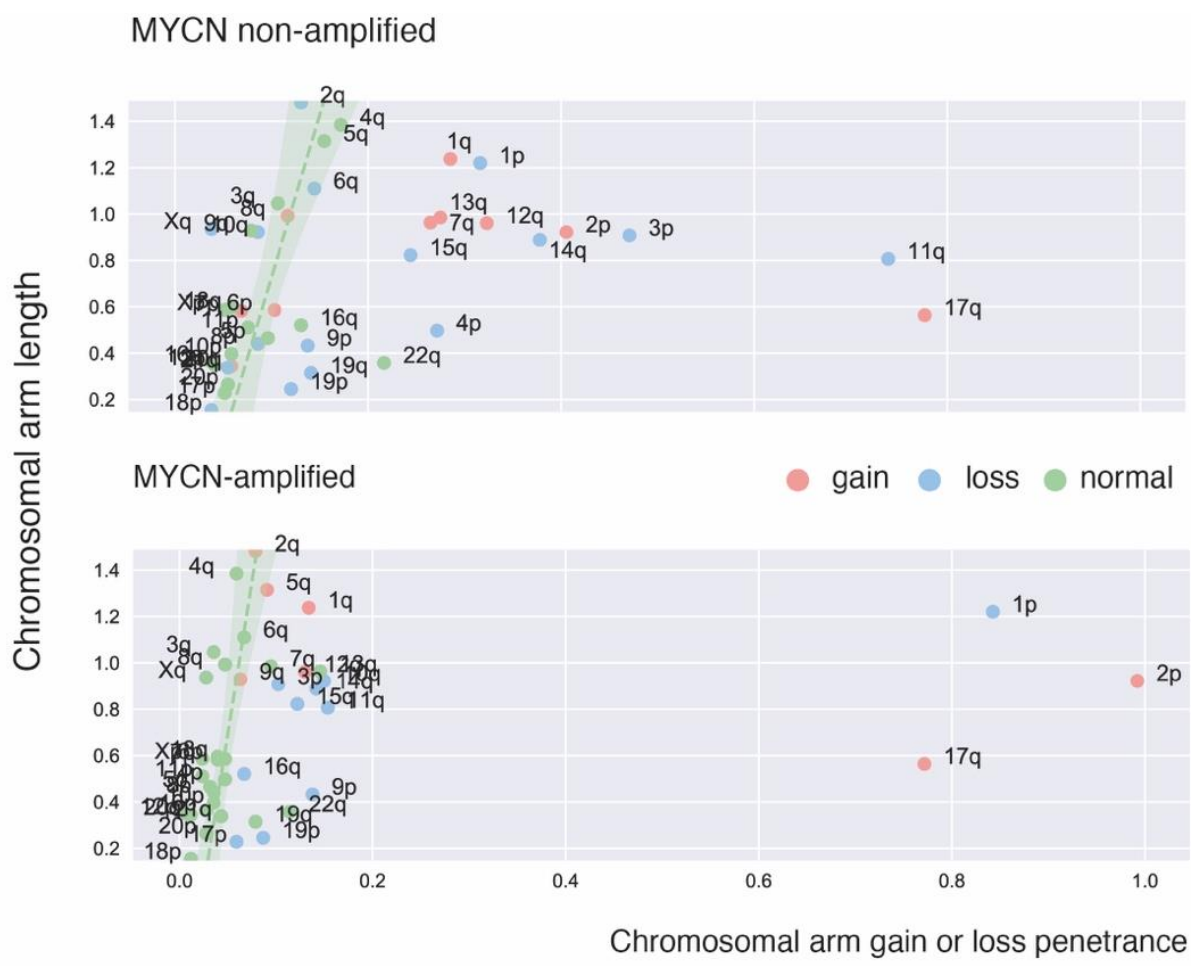

Figure 1. Correlation between chromosome arm length and amount of gains and/or losses on the arm in a dataset of 542 high-risk primary NB tumors [38] showing recurrent copy number imbalances in MYCN non-amplified and MYCN-amplified tumors. Gains or losses that spanned both chromosomal arms where not withhold. For every chromosomal arm the ratio of gains versus losses was analyzed in a binomial test to establish whether either the number of gains was exceptional in respect to the number of losses or the other way around. If a significant amount of gains was found for the total number of gains and losses, the chromosomal arm is displayed in red, if the other way around in blue, and if both losses and gains on the arm were on par ( $p$-value binomial test $\geq 0.05$ ) they are displayed in green. The 'green' arms were used to calculate a linear regression between chromosomal arm length and total number of combined losses and gains. The standard deviation on this linear regression is depicted in a shaded green area to indicate where normal amounts of gains and losses lie for the chromosome arms of different length. Outliers can now easily be identified in the two $M Y C N$ groups and comprise the usual suspects. 
Segmental chromosomal gains in general, and chromosome 17q gain in particular, were found to be associated with poor survival $[19,35,39]$. To identify genomic aberrations associated with poor outcome in high-risk NB, we applied logistic and Cox proportional hazard regression on CNAs from 556 high-risk NBs obtained at diagnosis [33,38]. Using this approach, we identified two types of CNAs that are associated with an extremely poor prognosis: (1) distal chromosome $6 \mathrm{q}$ losses detected in $5.9 \%$ of patients and associated with a 10-year overall survival probability of only $3.4 \%$ and (2) amplifications of regions not encompassing the $M Y C N$ locus detected in $18.1 \%$ of patients [( 2 p25.1 encompassing the ODC1 locus (12 samples), 2p23.2 including ALK (5), 2p25.1 including GREB1/NTSR2 (4), 6q16.3 including LIN28B (3), 12q15 including MDM2(2), 12q13.3/14.1 including CDK4 (2), 11q13.2/13.3 including MYEOV and CCND1 (2), and 5p15.33 including TERT (2). Several other amplicons, including 8q24.21 encompassing the MYC gene (1 sample)] and associated with a 10-year overall survival probability of only $5.8 \%$ [38].

DNA arrays with increased resolution and ultimately whole genome sequencing allowed reliable detection of smaller focal copy number alterations or indels and paved the way for the identification of several novel genes critically involved in NB. Whole genome sequencing unveiled chromothripsis as a mechanism driving complex multi-locus rearrangements causing combined amplification, deletion, gain and structural variants affecting particular loci [40]. Circle-sequencing further dissected the landscape of small and large extra chromosomal DNA in NB (respectively eccDNA and ecDNA) [41,42]. Large ecDNAs detectable as double minutes encompass entire genes and are associated with elevated expression levels of amplified genes. A recent experimental study on DHFR amplification under methotrexate exposure revealed that chromothripsis not only drives ecDNA formation but is also implicated in further ecDNA evolution [43]. In NB, chromosomal circle integration was shown to preferentially affect tumor suppressor genes and thus may further shape genomic evolution of these cancer cells [42].

\section{DNA Copy Number Affected Genes Supporting MYCN Activity}

In an early DNA copy number analyses, we identified several focal aberrations affecting genes that were connected to $M Y C N$ regulation or activity [44]. Taken together, a picture emerges where DNA copy number affected regions seem to be embedded within the tumor genome under the selective pressure to increasingly support $M Y C N$ activity in these cells. Here below we describe in more detail the key copy number driven genes with an established role in regulating MYCN activity (Figures 2 and 3).

\subsection{ALK}

The anaplastic lymphoma kinase gene, typically present as fusion genes in anaplastic large cell lymphoma and a subset of lung cancers, was also found to be implicated in NB development. Activating ALK genetic alterations occur in $8-10 \%$ of all NB cases, and are mostly missense mutations affecting the ATP-binding pocket, with $A L K$ amplifications found in a small subset of tumors. In addition, germline variants of $A L K$ are found in familial NB cases supporting a bona fide oncogenic driver effect for activating $A L K$ mutations in humans [7-11,45]. In $A L K$ amplified cases, $M Y C N$ is typically co-amplified [45]. Both genes are located on the short arm of chromosome 2 which is often gained in high-risk NB and $M Y C N / A L K$ co-amplification typically results from a chromothripsis event involving the chromosome 2 short arm [40]. Remarkably, in mouse and zebrafish, ALK mutations are not sufficient as a single lesion to drive NB formation but $A L K$ activating mutations do significantly accelerate $M Y C N$ driven NB formation [46-48]. Further support for functional interaction between mutant $A L K$ and $M Y C N$ was provided by neuroendocrine prostate cancer research where activated $A L K$ was shown to cooperate with $M Y C N$ via Wnt/ $\beta$-catenin signaling [49]. 


\begin{tabular}{|c|c|c|c|c|c|}
\hline Gene & Chromosomal location & Band & Main function & in vivo overexpression model & Drugs on target \\
\hline MYCN & chr2:15940550-15947007 & p24.3 & MYCN activity & mouse $[22,46,47,50]$, zebrafish [48] & \\
\hline$A L K$ & chr2:29192774-29921586 & p23.1 & $\sim$ MYCN activity $[40,45]$ & mouse [46,47], zebrafish [48] & Lorlatinib [51-53] \\
\hline LIN28B & chr6:104936616-105083332 & $\mathrm{q} 16.3$ & $\sim \mathrm{MYCN}$ activity [54-58] & mouse [54], zebrafish [59] & \\
\hline MiR-17 92 & chr13:91347820-91354579 & $\mathrm{q} 31.3$ & $\sim$ MYCN activity [60-67] & & \\
\hline ALYREF & chr17:81887835-81891586 & q25.3 & MYCN activity [68] & & \\
\hline MYC & chr8:127735434-127742951 & q24.21 & MYCN activity $[69,70]$ & & \\
\hline CDK4 & chr12:57747727-57756013 & $\mathrm{q} 14.1$ & Cell cycle [71-75] & & Ribociclib [76-80] \\
\hline CCND1 & chr11:69641156-69654474 & $\mathrm{q} 13.3$ & Cell cycle $[23,75,81]$ & & \\
\hline TRIM37 & chr17:58982638-59106921 & q22 & Cell cycle [82] & & \\
\hline MDM2 & chr12:68808177-68845544 & $\mathrm{q} 15$ & TP53 pathway [83-95] & & Nutlin-3 [96-101] \\
\hline BIRC5 & chr17:78214186-78225636 & $\mathrm{q} 25.3$ & Survival $[102,103]$ & zebrafish (in review) & Sepantronium Bromide [104-107] \\
\hline TBX2 & chr17:61399843-61409466 & $\mathrm{q} 23.2$ & Transcriptional Addiction $[108,109]$ & & \\
\hline JMJD6 & chr17:76712832-76726799 & q25.1 & Transcriptional Addiction [110] & & \\
\hline SOX11 & chr2:5692384-5701385 & p25.2 & Transcriptional Addiction $[111,112]$ & & \\
\hline SOX9 & chr17:72121020-72126416 & $\mathrm{q} 24.3$ & Transcriptional Addiction [113-115] & & \\
\hline PPM1D & chr17:60600183-60666280 & $\mathrm{q} 23.2$ & DNA damage and RS $[116,117]$ & mouse [117] & \\
\hline$B R C A 1$ & chr17:43044295-43170245 & q21.31 & DNA damage and RS [118] & & \\
\hline$B R I P 1$ & chr17:61679139-61863559 & $\mathrm{q} 23.2$ & DNA damage and RS [116] & zebrafish (in preparation) & \\
\hline$C D K 12$ & chr17:39461486-39564907 & $q 12$ & DNA damage and RS $[119,120]$ & & THZ531, BSJ-01-175 [121-124] \\
\hline RRM2 & chr2:10120698-10211725 & p25.1 & $\begin{array}{l}\text { DNA damage and RS [125-128] } \\
\qquad R S=\text { Replicative Stress }\end{array}$ & zebrafish [125] & Triapine [125] \\
\hline
\end{tabular}

$\%$ with gain or loss

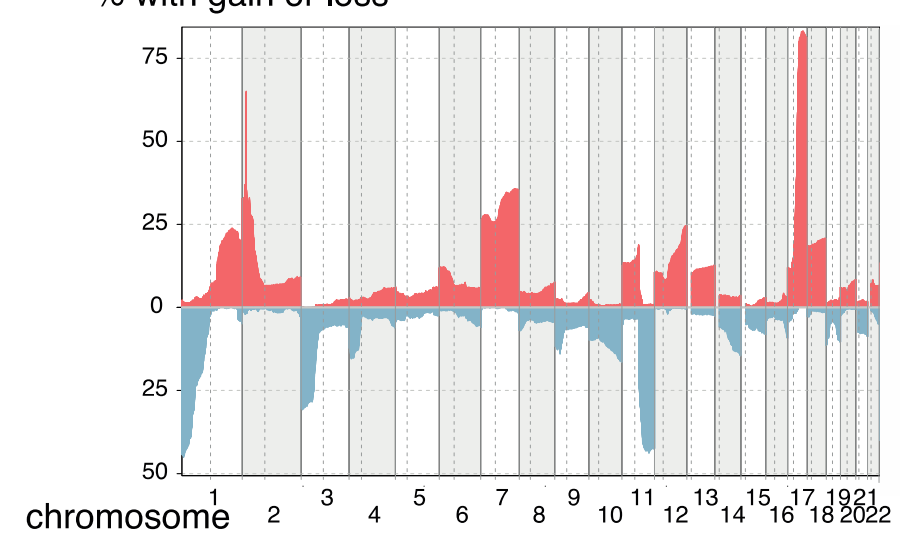

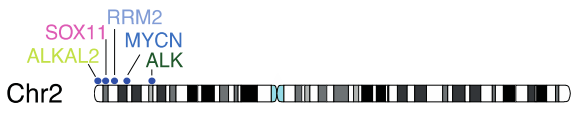

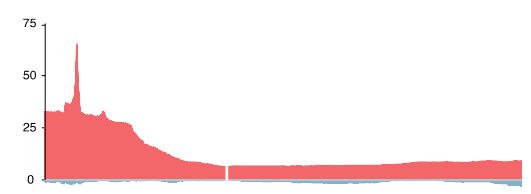

Chr6

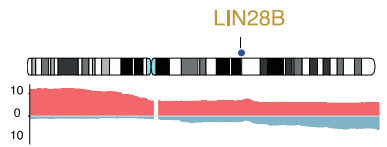

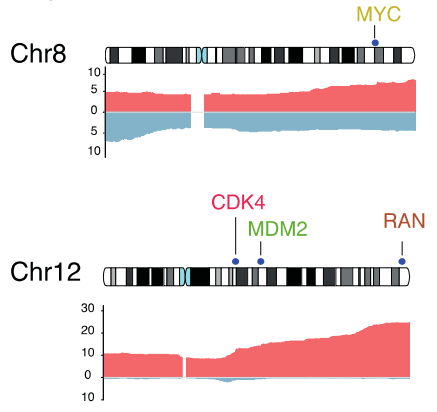
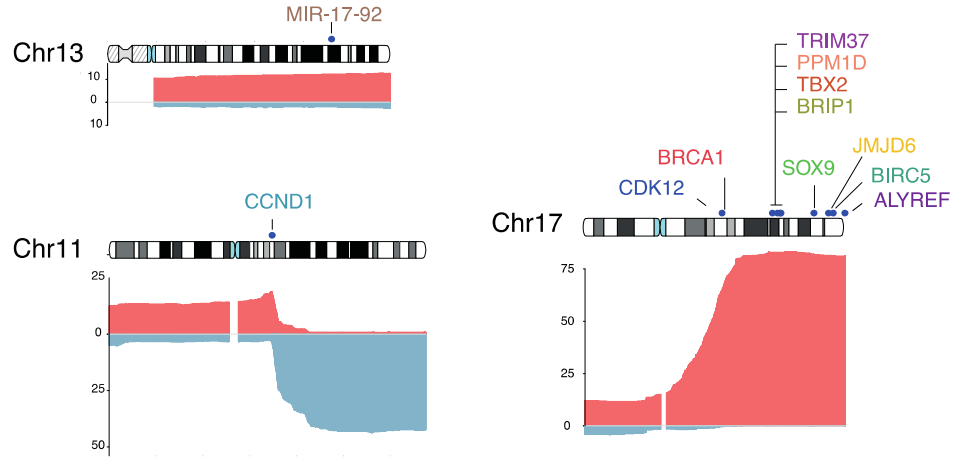

Figure 2. Table describing the copy number affected genes discussed in this review, their chromosomal location and cytoband, their main function with references, in vivo modeling with references, and drugs on target with references. Frequency of copy number gains/amplifications (red) and losses (blue) for chromosomes 1 to 22 in 542 high-risk NB samples with segmental CNAs [38]. Copy number affected genes in NB that were discussed in this review are depicted on their chromosome with the associated copy number frequency (chromosome 2, 6, 8, 11, 12, 13 and 17). Refs. [22,23,40,45-48,50-128] are cited in Figure 2. 
Following knockdown or pharmacological inhibition of mutant $A L K$ in NB, we performed transcriptome profiling and found that downstream signaling is mediated through the RAS/MAPK and PI3K/AKT pathways [129]. For each of these downstream signaling axes we identified a key component that could explain the increased aggressiveness of $M Y C N / A L K$ activated NB cells, i.e., (1) RAS/MAPK/ERK signaling activated the ETV5 transcription factor which controlled migration, invasion and colony formation in vitro and proliferation in a murine xenograft model ([130], p. 5) and (2) the PI3K/AKT/FOXO3a regulated 'HMG-box transcription factor 1' (HBP1) which inhibits both the transcriptional activating and repressing activity of $M Y C N$. Of further interest, HBP1 itself is under negative control of MYCN through miR-17 92. Combined targeting of HBP1 by PI3K antagonists and MYCN signaling by BET- or HDAC-inhibitors blocks MYCN activity and significantly reduces tumor growth, suggesting a novel targeted therapy option for high-risk NB ([131], p. 1). Using a detailed proteomics analysis of the mutant $A L K$ signaling components in $\mathrm{NB}$, the signaling adaptor protein 'insulin receptor substrate 2' (IRS2) was also identified as a major $A L K$ downstream target further controlling the PI3K/AKT/FOXO3a axis [132]. Finally, we also noted that mutant $A L K$ upregulates RET and RET-driven sympathetic neuronal markers of the cholinergic lineage [129] which is intriguing in the light of the recent finding that malignant cells enriched in high-risk NB resemble a subtype of TRKB+ cholinergic progenitor population identified in the human post-natal gland [133].

At present, constitutive $A L K$ activation through mutation or amplification is the most accessible target for precision medicine in NB [7-11] with a recently initiated clinical trial for the 3rd generation $A L K$ inhibitor Lorlatinib [51-53]. Remarkably, the gene encoding the $A L K$ ligand $A L K A L 2$ is located on the distal 2p segment (2p25.3). In view of the highly recurrent distal $2 \mathrm{p}$ gains in high-risk NBs this suggests that, in addition to increased expression levels of $M Y C N$ in cases of $M Y C N$ non-amplified tumors, an extra copy of the $A L K$ gene and the gene for its ligand could impact tumor formation. The Palmer team recently investigated whether the ALKAL2 ligand could potentiate NB progression in the absence of $A L K$ mutation and showed that $A L K A L 2$ overexpression in mice drives ALK TKIsensitive NB in the absence of $A L K$ mutation. Consequently, both $A L K$ mutated/amplified as well as 2p-gain high-risk NBs with elevated $A L K / A L K A L 2$ protein, may benefit from $A L K$ tyrosine kinase inhibitor-based therapeutic intervention [134].

\section{2. $\operatorname{LIN} 28 B$}

The discovery of LIN28B involvement in NB was triggered through the finding of a new amplified region on chromosome 6q21 in three high-risk NB tumors in a dataset of 263 tumors [54] as well as a GWAS study [54,55]. The smallest region of overlap (SRO) of the discovered amplicons in the first study encompassed four genes, including LIN28B. LIN28B overexpression was identified in three independent NB tumor series compared to normal reference tissues and a series of tissues from other malignancies. Most importantly, analysis of LIN28B expression showed pronounced overexpression in the tumors with LIN28B amplification while Kaplan-Meier analyses showed that high expression of LIN28B was significantly associated with poor overall survival in two cohorts of 88 and 283 patients with NB [54]. LIN28B is a key regulator of developmental processes by modulating microRNAs (miRNAs) of the let-7 family. LIN28B represses the let-7 miRNAs which consequently results in elevated $M Y C N$ protein expression in NB cells. Molenaar et al. further showed that LIN28B-let-7-MYCN signaling blocked differentiation of normal neuroblasts and NB cells. They recapitulated these findings in a mouse model in which LIN28B expression in the sympathetic adrenergic lineage induced development of NBs marked by low let-7 miRNA levels and high MYCN protein expression [54]. In a subsequent study, we performed a comprehensive analysis of the regulation of $L I N 28 B$ in NB, with a specific focus on the contribution of miRNAs and showed that $M Y C N$ regulates LIN28B expression in NB tumors via two parallel mechanisms. First, using an unbiased LIN28B-3'UTR reporter screen, we found that miR-26a-5p and miR-26b-5p regulate LIN28B expression. We provided evidence that $M Y C N$ indirectly regulates the expression of miR-26a-5p, which on its turn reduces 
LIN28B levels, therefore establishing an MYCN-miR-26a-5p-LIN28B regulatory axis [56]. Second we demonstrated that $M Y C N$ regulates $L I N 28 B$ expression via interaction with the LIN28B promoter, establishing a direct MYCN-LIN28B regulatory axis [56]. In addition, another study revealed 'PDZ Binding Kinase' (PBK) as a novel LIN28B target with implication in NB, repressed by let-7 and positively regulated by $M Y C N$ [57]. Further insights into the role of LIN28B in NB was provided by the Diskin team who identified the oncogene RAN, located on chromosome 12, as a LIN28B direct RNA target. They further showed that regional gains of chromosome 12q24 as an additional somatic alteration resulted in increased RAN expression. LIN28B influences RAN expression by promoting 'RAN Binding Protein $2^{\prime}$ (RANBP2) expression in a let-7-dependent manner and by directly binding RAN mRNA. Aurora kinase A (AURKA) was found to be activated by both RAN and LIN28B through phosphorylation and let-7-mediated repression respectively [58]. Remarkably, the Look team discovered a let-7 independent function for LIN28B in NB development through the analysis of overexpression of wild-type (WT) LIN28B and a LIN28B mutant that is unable to inhibit let-7 processing. Unexpectedly, both increase the penetrance of $M Y C N$-induced NB, potentiate the invasion and migration of transformed sympathetic neuroblasts, and drive distant metastases in vivo in zebrafish. Genome-wide chromatin immunoprecipitation coupled with DNA sequencing and co-immunoprecipitation experiments showed that LIN28B is recruited to active gene promoters in NB cells through protein-protein interaction with the sequence-specific zinc-finger transcription factor ZNF143 [59]. The activated downstream targets include transcription factors forming the adrenergic core regulatory circuitry that control the malignant cell state in NB $[108,135,136]$ as well as GSK3B and L1CAM that are involved in neuronal cell adhesion and migration [59].

\section{3. $M i R-17 \sim 92$}

The oncogenic miR-17 92 cluster consists of six individual miRNAs (miR-17, miR-18a, miR-19a, miR-19b, miR-20a, and miR-92a) located within a polycistronic transcript on human chromosome 13 and is widely implicated in cancer [60-62]. Overexpression can result from amplification of the miR-17 92 locus [60] or direct miR-17 92 transactivation by c-MYC/MYCN [63-65]. The oncogenic nature of miR-17 92 activation is supported by the identification of miR-17 92 targets with key roles in cell-cycle control and cell death. In particular, miR-17 and miR-20a target the cyclin-dependent kinase inhibitor CDKN1A (p21), a negative regulator of the G1-S transition, and miR-17 targets the proapoptotic BCL2L11 gene (Bim) [63]. The Ventura team performed a groundbreaking in vivo study to further unravel the role of the individual members of this cluster and found, amongst others, a role for miR-19 in Myc-driven tumorigenesis in two models of human cancer [66]. Investigation of a large series of NB cases revealed one tumor with a small focal gain of the chromosome 13q31.3 region encompassing the miR-17 92 locus as only locus present in this focal gain, further indicating a supportive role for enhanced expression levels of one or more miRs from this cluster and selective pressure during the tumor formation process for those cells carrying an extra copy of the locus [44]. Using combined SILAC and quantitative mass spectrometry, the effects of activation of the miR-17 92 cluster on global protein expression in NB cells were investigated showing cooperation between individual miR-17 92 miRNAs and implicating miR-17 92 in multiple hallmarks of cancer, including proliferation and cell adhesion [65]. In this study, miR-17 92 was found to act as a potent inhibitor of TGF- $\beta$ signaling through affecting both upstream and downstream regulators of pSMAD2 thus triggering downregulation of multiple key effectors along the TGF- $\beta$ signaling cascade as well as direct inhibition of TGF- $\beta$-responsive genes. Of further note, using an integrated approach including miRNA and messenger RNA (mRNA) gene expression data it was shown that c-MYC/MYCN induced, in addition to the miR-17 92 cluster, a broader core set of miRNAs for cooperative repression of common transcriptional programs related to disease aggressiveness [67]. 


\subsection{ALYREF}

The Marshall team used a bioinformatic approach to identify critical genes on 17q in high-risk NBs by evaluating frequency of gains distal to 17q21.31 using whole genome sequencing data from NB tumors from the US TARGET database [68]. A total of 1044 transcripts from the 17q21-ter locus were analyzed for differential gene expression in 17q21-tergain patients (1) and $M Y C N$-amplified patients (2) in the same cohort. Further correlation with gene copy number (3) and $M Y C N$ expression (4) as well as association with poor NB patient outcome (5) were taken into account. Using this approach, ALYREF was the only gene to pass all five criteria among the 1044 17q21-ter genes, and suggests that $M Y C N$ and ALYREF co-operate as tumorigenic factors in NB. Further functional studies revealed that $M Y C N$ increases NB cell viability in an ALYREF-dependent manner and directly regulates ALYREF transcription. The known role of $A L Y R E F$ as a regulator of DNA binding guided further analyses that uncovered $A L Y R E F-M Y C N$ interaction in a nuclear coactivator complex which stimulates transcription of the 'ubiquitin specific peptidase 3' (USP3), consequently reducing $M Y C N$ ubiquitination and degradation. This finding therefore opens novel opportunities for targeting this deubiquitinase activity through the development of USP3 inhibitors [68].

\subsection{MYC}

Given that MYC also drives expression of the miR-17 92 locus it would not be unexpected that MYC overexpression could also cause NB and that MYC could be a target for amplification in a subset of NB. We first reported a bona fide NB cell line with evidence for a chromothripsis event involving amongst others multiple chromosome 8q loci including MYC [69]. More recently, the Look team reported amplification of critical enhancers controlling MYC expression in a subset of NBs as well as structural rearrangements leading to enhancer hijacking [70].

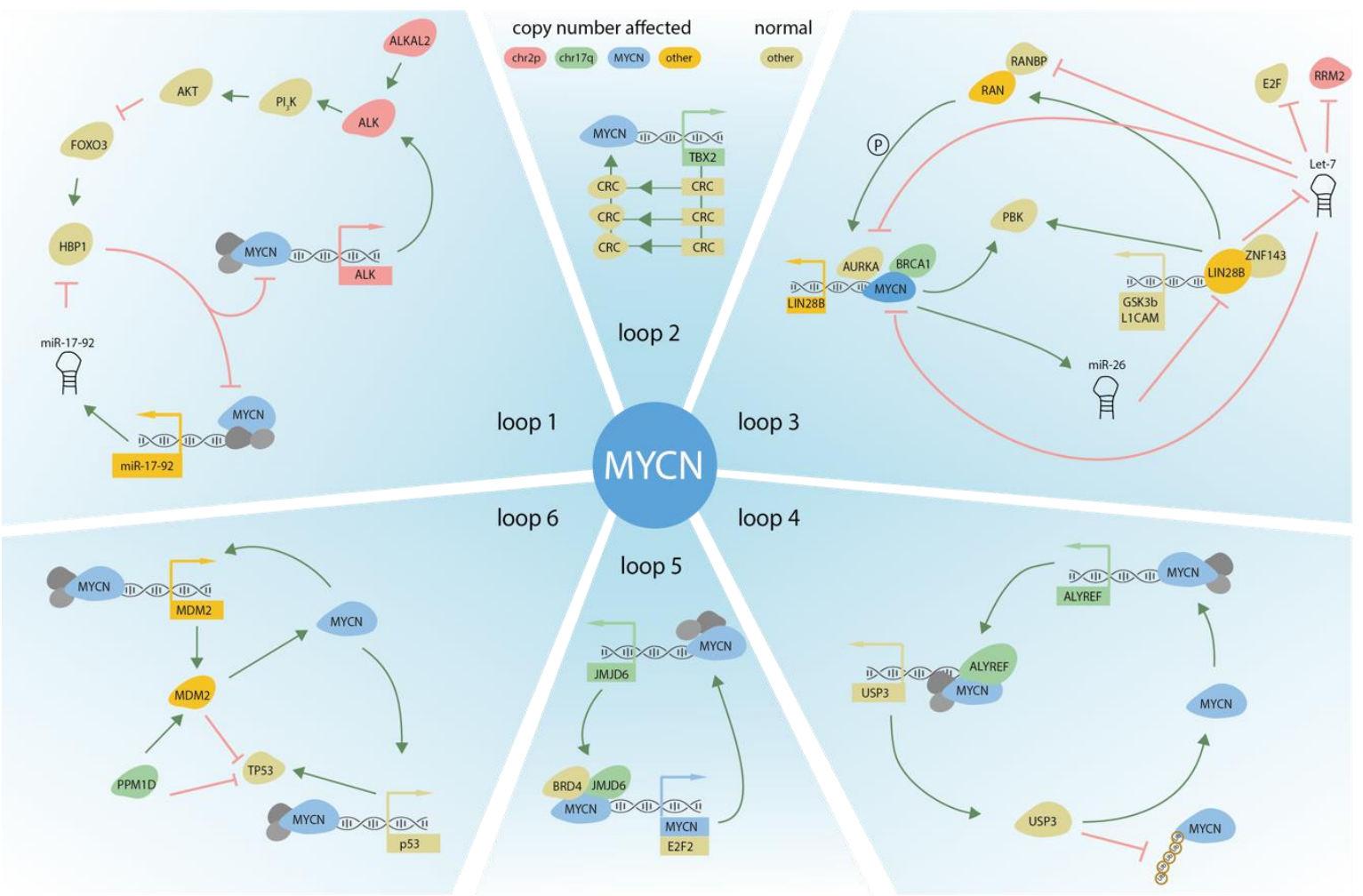

Figure 3. DNA copy number affected genes and their upstream and downstream regulators, supporting MYCN activity in NB. Six different autoregulatory loops are depicted. Color of the proteins (circles) or genes (square) indicates the genomic location of the CNA. 


\section{DNA Copy Number Affected Genes Driving Cell Cycle Activity 4.1. $C D K 4 / C C N D 1$}

Already in 1995, we found evidence for amplification of a region encompassing several putative oncogenes on the long arm of chromosome 12 including SAS, MDM2, CDK4, GLI, CHOP and CDK2 [71]. Decrease in Cdk2 abundance and loss of CDK4 activity was observed in a mouse NB cell line upon neuronal differentiation in response to DMSO [72]. Gains and amplification of the CDK4 regulatory subunit 'cyclin D1' (CCND1) were detected in early DNA copy number profiling efforts of high-risk NBs. In most cases the CCND1 gains were accompanying large 11q deletions in MYCN non-amplified tumors [30]. In a recent whole genome profiling study of 205 high-risk cases Brady et al. confirmed the association of 11q13.3 copy number gains with the chromosome 11 deletions (resulting from unbalanced translocations) resulting in significant increased CCND1 expression [23].

Dependency on CCND1 and CDK4 for NB survival and proliferation was demonstrated and a functional dependency on overexpression of G1-regulating genes to maintain the undifferentiated phenotype was shown [81]. In line with these findings, another study investigated genome-wide copy number alterations and transcriptomes in $82 \mathrm{NB}$ tumors showing that nearly $30 \%$ of all tumors had genomic amplifications, gains, or losses with shortest regions of overlap that suggested implication of a series of G1 cell cycle regulating genes. This included the above mentioned CCND1 and CDK4 which were amplified or gained and the chromosomal regions containing the CDKN2 (INK4) group of CDKIs which were frequently deleted. Cluster analysis showed that tumors with genomic aberrations in G1 regulating genes over-expressed E2F target genes, which regulate $S$ and G2/M phase progression [137]. This was further explored in the context of doxorubicin induced DNA damage response. The altered CDK4/cyclin D-pRB axis in $M Y C N$-amplified NB cells allowed to evade a G1/S arrest after doxorubicin-induced DNA damage. Additional chromosomal aberrations affecting the p53-p21 and CDK4-pRB axes further enhance the effects of $M Y C N$ on the G1 checkpoint and reduce sensitivity to cell death after doxorubicin treatment. CDK4 inhibition partly restores G1/S arrest and sensitizes cells to doxorubicinmediated cell death in $M Y C N$-amplified cells with an intact p53 pathway [73]. Taken together, these studies identified proteins controlling the critical G1/S restriction point as putative therapeutic targets for high-risk NB [74]. Using an siRNA library for 131 cell cycle regulators, we found CCND1 and PLK1 as top hits and further investigated the effects of a small molecule compound palbociclib which is a potent and highly selective inhibitor of CDK4 and CDK6. NB cell lines IMR-32, SH-SY5Y, and NGP responded in a time- and dose-dependent manner with reduced proliferation while SK-N-SH and CLB-GA cells were relatively resistant to the treatment and other cell lines such as SH-EP responded at relatively high concentrations [75]. The Maris team evaluated the effect of dual CDK4/CDK6 inhibition on NB viability using the highly specific CDK4/ 6 inhibitor ribociclib (LEE011, Novartis Oncology, Basel, Switserland) showing the expected reduction in proliferation in 12 of 17 human NB-derived cell lines through cell-cycle arrest and cellular senescence [76]. More recently, a phase I clinical trial was conducted with ribociclib in pediatric cancer patients to test safety and pharmacokinetics with positive results [77]. Next, the combination of ribociclib and the $A L K$ inhibitor ceritinib were tested showing a higher cytotoxicity and synergy scores in cell lines with $A L K$ mutations as compared with cell lines lacking mutations or alterations in $A L K$. Combination therapy achieved complete sustained regressions in NB xenografts with $A L K-\mathrm{F} 1174 \mathrm{~L}$ and F1245C de novo mutations and prevented the emergence of resistance. Murine ribociclib and ceritinib plasma concentrations were unaltered by the use of combination therapy [78]. Synergistic interaction with ribociclib was also found for MEK1/2 inhibition [79]. In contrast, combined drugging of CDK4/ 6 and MDM2 activity did not show noticeable synergistic effects [80].

\subsection{TRIM37}

TRIM37, the centrosomal ubiquitin ligase on chromosome $17 \mathrm{q}$, was identified as a top hit in a genome-wide screen for genes whose inactivation enables sustained proliferation 
of PLK4 inhibitor (centrinone) treated retinal pigment epithelium (RPE1) cells. Loss of TRIM37 rescued the delayed spindle assembly and chromosome-segregation failure seen in cells that lack centrosomes treated with centrinone. Further analyses revealed that TRIM37 is an essential determinant of mitotic vulnerability to PLK4 inhibition: low TRIM37 levels accelerate acentrosomal spindle assembly and improve proliferation following PLK4 inhibition, whereas high TRIM37 levels inhibit acentrosomal spindle assembly, leading to mitotic failure and cessation of proliferation. NB and breast cancer cells with gain of chr17q were found to be highly sensitive to PLK4 inhibition [82].

\section{DNA Copy Number Affected Genes Involved in TP53 Pathway Control} 5.1. MDM2

The first evidence for MDM2 amplification in NB was reported by Waber et al. [138] in 1993 and later confirmed by several other studies [71,83-85]. As indicated above, multiple other loci are often co-amplified and more complex amplification patterns affecting distinct chromosome 12q chromosomal segments hint towards chromothripsis causing events. The p53 function is inhibited by MDM2, and while TP53 mutations are rather rare in NB, its occurrence is associated with relapse cases [86]. Mutations in the RAS or p53 pathway increases tumor aggressiveness in the high-risk cases defined by telomere maintenance, while this is not the case in low-risk tumors [139]. Multiple studies pointed towards disruption of the TP53/MDM2/p14 signaling axis in wild-type p53 NB and the functional consequences have been extensively investigated [87-90]. In addition to its canonical function as p53 inhibitor, the MDM2 ubiquitin ligase also controls MYCN protein stability which itself drives MDM2 expression through promotor binding and transcriptional activation [91-95]. Importantly, MDM2 overexpression and dependency offers a target for precision drugging given the potential to disrupt MDM2-p53 proteinprotein interaction in TP53 wild type NB cells. Using a low-molecular-weight compound that competes with p53 for binding into a hydrophobic cleft on the surface of MDM2, termed nutlin-3 [96], we have been able to elicit a robust and selective activation of the p53 pathway in NB cells with wild-type p53, leading to G1 cell cycle arrest, apoptosis, premature senescence and neuronal differentiation [97]. MDM2 inhibition by nutlin-3 also dramatically sensitizes NB cells to chemotherapy-induced apoptotic cell death [98], and nutlin-3 can reverse P-glycoprotein-mediated multidrug resistance of NB cells regardless of TP53 mutation status [99]. These findings prompted further exploration of nutlin-3 derivatives for novel clinical trials in pediatric tumors including NB [100,101].

\subsection{BIRC5}

Survivin, encoded by the BIRC5 locus is an essential protein for cell division and can inhibit cell death in most, if not all cancers including high-risk NBs. Of further interest, the BIRC5 gene maps to the commonly gained $17 \mathrm{q}$ segment and thus could represent a bona fide target affect by extra 17q copies [102,103]. Given that survivin is the fourth most upregulated mRNA in the human cancer transcriptome [140] and its expression has been correlated with increased tumour resistance to a broad range of chemotherapy agents, radiation insensitivity and poor patient prognosis, it has been investigated as target for therapeutic intervention. Currently, the best-studied survivin suppressor is YM155 (sepantronium bromide) which has been tested with variable results [104]. A recent paper has validated the role of survivin in NB development and describes the potential of utilizing survivin as drug target. It was shown that co-overexpression of BIRC5 in Tg(d $\beta$ h:eGFP$M Y C N)$ transgenic zebrafish promotes the development and growth of MYCN-driven NB (Dolman et al., in review) in keeping with data from Hipp et al. showing that survivin enhanced the tumorigenic functions of $M Y C N$ in Rat1 fibroblasts [105]. Recently, Michaelis et al. found no difference in efficacy of response to sepantronium bromide between $M Y C N$ non-amplified and $M Y C N$-amplified in vitro NB model systems [106]. In vivo analyses in mice showed strong response to sepantronium bromide for KCNR NB cells [107]. Further efforts to identify potent on-target surviving inhibitors are ongoing in- 
cluding the search for small molecule inhibitors of the survivin dimerisation interface [141], or adjacent cavities [142], antibodies binding to a cell surface pool of survivin [143], and short interfering RNA directing survivin which is encapsulated in nanoparticles [144].

\section{DNA Copy Number Affected Genes Driving Transcriptional Addiction}

\subsection{TBX2}

Given the established important role of super-enhancer marked transcription factor encoding loci in several cancer entities we set out to identify such candidates residing on chromosome 17q. The 'T-box 2 transcription factor' (TBX2), a gene with unknown function in $\mathrm{NB}$, was prioritized as transcription factor with top-ranked super-enhancer score in NB cell lines and with expression levels highly correlated with survival outcome in NB tumors [109]. Based on integrated analysis of the TBX2 genome-wide DNA binding pattern and transcriptome analysis upon knockdown, we identified TBX2 as novel member of the core regulatory circuitry that marks high-risk NBs. Similar findings were obtained using an unbiased genome-scale CRISPR screen identifying 147 candidate essential genes in $M Y C N$-amplified NB cell lines, pinpointing TBX2 as member of the core regulatory circuitry in $M Y C N$-amplified NB [108]. Our data suggest a role for TBX2 in positive control of E2F-FOXM1 signaling and proliferation. We propose that TBX2, as member of the core regulatory circuit, further enhances $M Y C N$ driven proliferation. Combined pharmacological targeting of transcriptional addiction using a BET (JQ1) and CDK7 (THZ1) inhibitor, yielded synergistic effects on TBX2 downregulation leading to massive apoptosis.

\subsection{JMJD6}

To further identify transcriptional regulators affected by $17 \mathrm{q}$ gains, the Tao team looked for candidates and identified the 'Jumonji domain-containing 6' (JMJD6) gene which encodes a dual arginine demethylase and lysyl hydroxylase of histone and nonhistone proteins. As a histone arginine demethylase, JMJD6 modulates RNA polymerase II release from promoter-proximal pause regions at target gene anti-pause enhancers by forming a protein complex with BRD4 and demethylating histone $\mathrm{H} 4$ at arginine 3 (H4R3) which consequently results in transcriptional activation. Whereas as a lysyl hydroxylase, JMJD6 also forms a protein complex with p53 and catalyzes p53 protein hydroxylation, which results in p53 inactivation. JMJD6 was shown to form protein complexes with MYCN and BRD4, controlling E2F2 and MYCN transcription, supporting proliferation and survival of NB cells. Combination therapy with the CDK7 (super-enhancer) inhibitor THZ1 and the histone deacetylase inhibitor panobinostat synergistically reduces JMJD6, E2F2 and $M Y C N$ expression, inducing apoptosis in vitro and causing NB tumor regression in mice [110].

\subsection{SOX11}

Our team identified SOX11 as putative dependency gene through a search for focal gains and/or amplifications of chromosomal segments encompassing transcription factors with a putative or known role in normal (neuronal) development. Re-analysis of NB DNA copy number profiling data revealed the sympatho-adrenal lineage specific SOX11 gene in recurrent chromosome $2 p$ focal gains and amplifications [111]. SOX11 is specifically expressed in adrenergic NBs and absent in mesenchymal NBs [111,112], two distinct superenhancer associated subtypes in NB [135,136]. Indeed, SOX11 is regulated by multiple adrenergic specific cis-acting (super-) enhancers, along with adrenergic NBs being strongly dependent on high SOX11 expression levels for growth and proliferation [111]. SOX11 was also shown to be involved in nucleokinesis in adrenergic NB cells [112]. We identified and validated functional SOX11 target genes through genome-wide DNA-binding and transcriptome analysis and identified several genes which are implicated in chromatin remodeling and epigenetic modification. Given the broad control of SOX11 on multiple epigenetic regulatory complexes and its presumed pioneer factor function [145], we hy- 
pothesize that adrenergic NB cells have co-opted the normal role of SOX11 as a crucial regulator of chromatin accessibility and cell identity [111].

\section{4. $5 O X 9$}

Large cohorts of NB patients have been studied using genome wide association (GWAS) analysis to identify NB predisposing loci. One such locus on 6p22.3 was further investigated and shown to encode CASC15 and NBAT1 lncRNAs acting as tumor suppressors with reduced expression in high-risk NBs. These lncRNAs were shown to repress SOX9 expression levels through CHD7 ([113], p. 9), a known regulator of neuronal differentiation and (super-) enhancer activity [114]. Of further interest, SOX9 is shown to be regulated by a mesenchymal-specific super-enhancer in NB [136], and plays a role in NB migration and invasion [115]. Given the SOX9 location on 17q25 which is commonly gained in high-risk $\mathrm{NB}$, it is conceivable that dosage effects of $S O X 9$ further enhance differentiation arrest during NB formation. Interestingly, CHD7 protein stability is regulated by the CASC15 and NBAT1 interactor USP36 which is also located on the chr17q gained region [113].

\section{DNA Copy Number Affected Genes Controlling DNA Damage and Replicative Stress Response}

7.1. $P P M 1 D / W I P 1$

While for other chromosomal regions discussed above, rare but recurrent high-level amplifications were found, for $17 q$ gains recurrently affected amplified regions are extremely rare. Through DNA copy number analysis of a less commonly used NB cell line M-PN-TS high level amplification of a small region encoding 15 genes (seven of which were consistently overexpressed, including PPM1D (WIP1)) was delineated. Further functional experiments revealed reduced proliferation and survival upon PPM1D knockdown [116]. In a recent analysis on 208 tumors with chromosome 17q gain, only three genes revealed to be present in the smallest region of overlap including PPM1D, RAD51C and BRIP1, and these chromosome $17 \mathrm{q}$ segmental gains were shown to further accumulate during clonal evolution. Furthermore, a gene fusion of PPM1D and BCAS3 was also found to be present in one NB tumor, subsequently resulting in accumulating PPM1D expression levels [117]. $P P M 1 D$ is a negative regulator of p53 and positively regulates MDM2 thus further enhancing p53 inhibition (Figure 3, loop 6) $[117,146]$. Using a CRISPR screen, wild-type P53 cell lines were shown to be dependent on PPM1D expression and PPM1D knockdown delayed tumor formation in vivo. PPM1D is also shown to be a critical regulator of DNA damage response by dephosporylating and inactivating ATM, ATR, CHK1, CHK2 and H2AX. A transgenic mouse model with PPM1D overexpression exposed to irradiation and thus DNA-damaging stress was able to develop PHOX2B-expressing neural crest-derived primary tumors of the adrenal gland phenotypically and genetically similar to NB [117]. Pharmacological inhibition of PPM1D selectively suppressed tumor growth of p53 wildtype NB cell lines [146] and of established NB xenografts in nude mice indicating that PPM1D might be a promising therapeutic target in p53 wild-type NBs [117].

\subsection{BRCA1, BRIP1, CDK12}

Three genes located on $17 \mathrm{q}$ are involved in the DNA repair pathway and upregulated during TH-MYCN driven NB formation in mice [147], possibly playing a role in NB and/or act as potential novel drug targets. CDK12 was shown to regulate DNA repair genes (including BRCA1 and BRIP1) through intronic polyadenylation $[119,120]$. Several CDK12 inhibitors have been developed and are currently under evaluation for clinical trials for other cancers, (p. 12 in [121-123]). Of further note, the Winter lab discovered a cyclin $\mathrm{K}$ molecular glue degrader which also efficiently depletes CDK12 and which could also represent a potentially important novel molecule for precision therapies [124].

Interestingly, the Eilers team attributed a novel function to the repertoire of the $B R C A 1$ gene. $M Y C N$ was found to recruit $B R C A 1$ to promoter-proximal regions preventing $M Y C N$ dependent accumulation of stalled RNAPII and enhancing transcriptional activation by 
MYCN. BRCA1 enables MYCN to suppress R-loop formation in promoter-proximal regions by stabilizing mRNA decapping complexes. The critical signal in $M Y C N$ that enables recruitment of $B R C A 1$ is the dephosphorylation of Thr58, which allows binding of the ubiquitin-specific protease USP11 and stabilizes MYCN and BRCA1 on chromatin, preventing proteasomal turnover of $M Y C N$ (Figure 3, loop 3) [118]. Mitoxantrone inhibits USP11 thus offering opportunities for targeting the BRCA1-MYCN interaction [148]. Because $B R C A 1$ is highly expressed in neuronal progenitor cells during early development and MYC is less efficient than $M Y C N$ in recruiting $B R C A 1$, the Eilers team suggests that a celllineage-specific stress response enables $M Y C N$-driven tumours to cope with deregulated RNAPII function. BRIP1 (BRCA1-interacting protein or FANCJ) maps in close proximity distal to PPM1D and TBX2 on 17q23.2 and has been implicated in unwinding of stable G-quadruplex DNA structures and acting through multiple mechanisms to the replication fork [116]. Our team is currently investigating the possible role of BRIP1 in further details including its effects in $M Y C N$ driven NB formation in a $M Y C N$ - driven zebrafish model.

\subsection{RRM2}

We recently identified the RRM2 gene as target for focal gains and amplifications in high-risk NBs, amongst others resulting from chromothripsis [125]. RRM2 encodes for the 'ribonucleotide reductase regulatory subunit 2' (RRM2) and together with RRM1 forms the RNR ribonucleotide reductase enzyme that ensures dNTP production essential for DNA replication and repair. $R R M 2$ has been proposed as driver oncogene in prostate cancer [126] and has been shown to play a critical role in melanoma [127] and Ewing sarcoma [128]. Based on its implication in focal amplifications and gains together with strong upregulation in development of TH-MYCN driven NB in mice and inverse correlation with survival in NB patients, our team further investigated the role of RRM2 through in vitro and in vivo experiments [125]. NB cell lines were shown to strongly depend on RRM2 for survival. Furthermore, a zebrafish $M Y C N / R R M 2$ co-overexpression model revealed a strong increase in tumor penetrance compared to $M Y C N$ only overexpressing animals. Finally, we demonstrated synergism for combined RRM2 and CHK1 inhibition thus pointing towards this drug vulnerability as an important future angle for therapeutic exploration [125].

\section{Evaluation of Gene Dependencies and Candidate Therapeutic Targets Using the Cancer Dependency Map}

In order to prioritize for essential genes and candidate therapeutic targets present on copy number affected lesions, NB tumor dependency has been investigated both in vitro and in vivo, as discussed above. However, public datasets can offer a first insight to prioritize candidate genes based on their association with survival and risk groups, other copy number affected genes, or tumor dependency. Using a recent public available CRISPR screen across 1032 cancer cell lines including 31 NB cell lines, genes can be evaluated for their NB dependency and specificity [149-151]. Figure 4 depicts the chromosomal locations and dependency scores based on this CRISPR screen for all the copy-number affected genes discussed in this review. For all of them, dependency is shown in NB. Of further interest, ALK, LIN28B, CCND1, PPM1D, TBX2, SOX11, MYCN and BRIP1 are strongly selective for NB as compared to other tumor entities, further highlighting these genes as potential drug targets (Figure 4). Recently, Dharia et al. created a firstgeneration Pediatric Cancer Dependency Map for 13 pediatric solid and brain tumor types, for which a full genomic characterization of $26 \mathrm{NB}$ cell lines and $180 \mathrm{NB}$ tumors was performed amongst other cellular entities and matched with genome-scale CRISPRCas9 loss-of-function screens. They showed that the number of selective dependencies does not correlate with the number of mutations or copy number alterations. These data could further be used to identify potential biomarkers for individual genetic dependencies, e.g., selective MDM2 dependency in TP53 wild-type cells. The vulnerabilities seen in childhood cancer were often different than what is observed in adult cancer, indicating that adult oncology drugs will be most of the times insufficient to treat pediatric cancers [152]. 

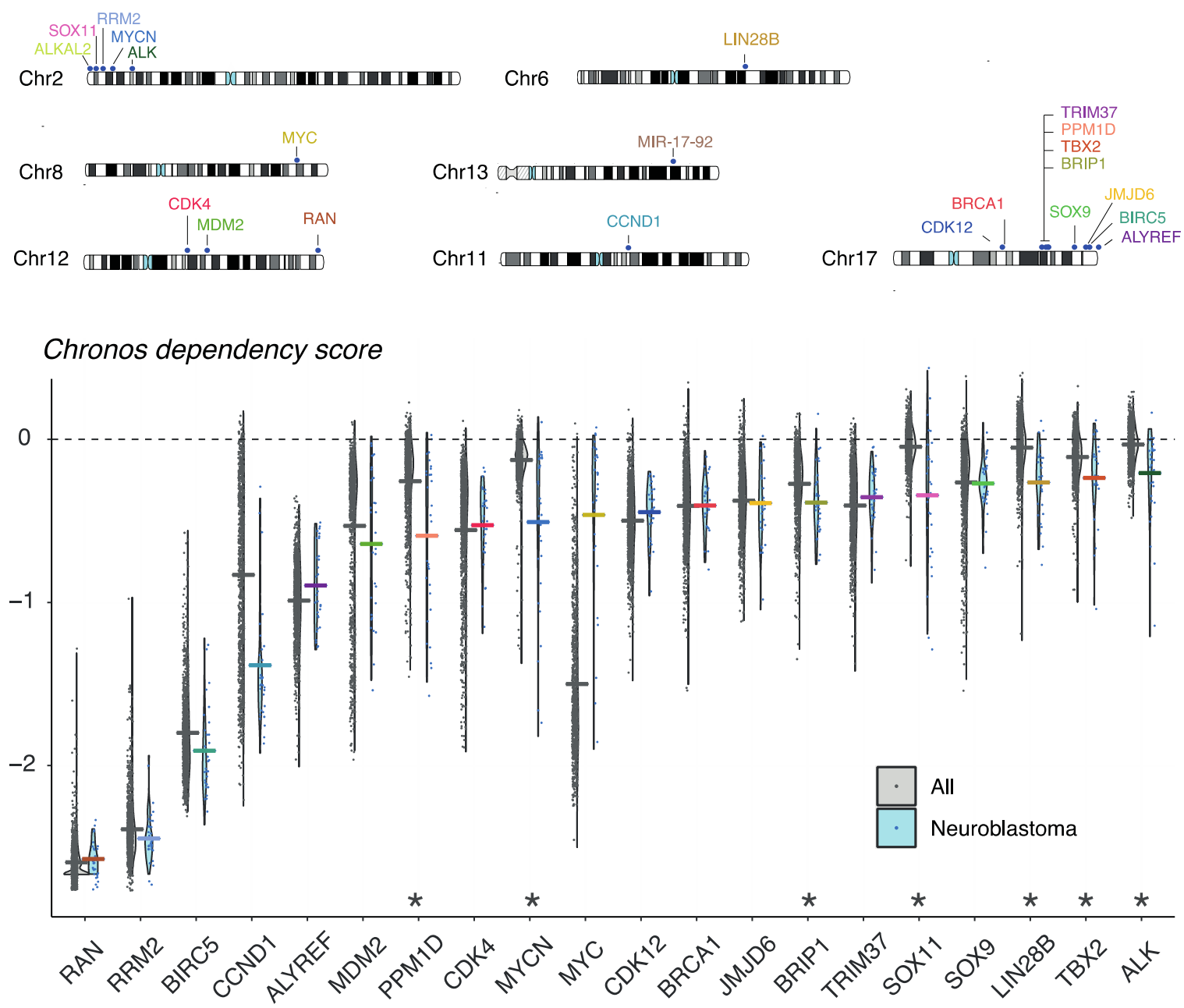

Figure 4. Copy number affected genes in NB that were discussed in this review are depicted on their chromosome (chromosome 2, 6, 8, 11,12, 13 and 17). Chronos dependency score for each copy number affected gene discussed in this review in a publicly available CRISPR screen across 1032 cancer cell lines (AVANA CRISPR 21Q3, available via the DepMap Portal). A lower Chronos score indicates a higher likelihood that the gene is essential for the cell line. Asterix means that the mean dependency score of the gene in NB cells (blue) is significantly lower than the mean dependency score in other cell lines (grey). Two-group comparison with $p$-value for each gene computed from empirical Bayes moderated t-statistic, enriched lineages are those with $p$-value $<0.0005$. Dependency scores for ALKAL2 and MIR-17-92 are not available.

\section{Current and Emerging In Vitro and In Vivo Models for Exploring the Role of DNA Copy Number Driven NB Dependencies}

Both mouse and zebrafish models have been established for $\mathrm{MYCN}$-driven NB formation $[22,46-48,50,54,59]$. In particular the zebrafish model has proven to be an efficient tool for testing co-dependencies as illustrated by successful studies for multiple candidates including mutant ALK [48], LMO1 [153], LIN28B [59], RRM2 ([125], p. 2), BIRC5 (Dolman et al., in review) and BRIP1 (Vanhauwaert et al., in preparation). One particular advantage of zebrafish models is access to early developing lesions that can be isolated by FACs sorting [154] and which is currently under further investigation in our lab for deeper exploration of early transforming events using single cell technologies. In addition to these approaches, the Freeman team has followed a unique approach to isolate immature neural crest cells from mouse embryos [155]. Subsequently, following transduction of these cells with a MYCN overexpression construct and injection into nude mice, it was shown that in most instances NB develop that recapitulate much of the molecular and cellular phenotype of mouse and human NBs, including CNAs syntenic as those observed in human e.g., 17q gain, $2 \mathrm{p}$ gain and $1 \mathrm{p} 36$ deletion. This model was also exploited to further study the role 
of ARID1A in the process of early tumor formation [156], a locus previously shown to be affected by deletions and alterations in NB [157], by CRISPR mediated induction of deletions encompassing the ARID1A locus [156]. In contrast to this model where the cells are subcutaneously injected into the flank of mice, Cohen et al. developed a NB model system by micro-injecting human pluripotent stem cell-derived NC cells with conditional MYCN and $A L K$ expression in utero into developing mouse embryos. These mouse-human neural crest chimeras developed tumors resembling human NB upon activation of the oncogenes by adding doxycycline to the drinking water [158]. So far, no one was able to engineer cells or animals with large chromosomal segmental gains for in vivo evaluation. However, using an in vitro embryonal stem cell model we could show that recurrent chromosomal segmental gains, including chromosome 17q amongst others, provide a proliferative advantage when cells are under increased replicative stress [159]. In vitro differentiation outside the developmental context of the normal neural crest is challenging, particularly for cells migrating during differentiation. Thus far, current in vitro models have been unable to reliably generate sympatho-adrenergic precursors, from which NB is presumed to develop. Our lab, in collaboration with the Studer laboratory at Memorial Sloan Kettering Cancer Center, has optimized and characterised a pluripotent stem cell-derived in vitro differentiation model to accurately generate the cells of interest. This allows us to study the normal sympathetic as well as NB development in vitro, using any available stem cell line carrying mutations of interest. We are currently utilizing this model to study MYCN-driven NB formation, where we induce $M Y C N$ overexpression during in vitro development to analyse the effect on development and malignant cell transformation. Using the 17q gained-stem cell line available in our lab, we are also in the process of studying the role of the 17q gain in $M Y C N$ driven NB. These state-of-the art experimental platforms are highly valuable to study NB tumor initiation, progression, manifestation, tumor-immune-system interaction and drug response in depth.

\section{Future Perspectives to Mine CNAs for Novel Candidates and Deeper Exploration of NB Dependency Genes}

Computational approaches have been developed and applied to mine genome-wide CNAs and gene expression profiles in order to identify novel tumor dependencies. One of the first algorithms, 'Copy Number and Expression In Cancer' (CONEXIC), is a module networks-based approach that integrates matched CNA and gene expression data from tumor samples to identify and score the combination of CNAs that best explain the behavior of a gene co-expression module across tumor samples [160]. CONEXIC correctly identified known drivers of melanoma and predicted multiple novel ones, some of which could be empirically confirmed. Meanwhile, several related methods have been reported that can integrate various multi-omics data and outperform CONEXIC both in computational runtime and ease of parameter setting, as well as in the prediction of consistent and functionally coherent co-expression modules and associated driver genes i.e., the regulators of the co-expression modules [161,162]. In this respect, Lemon-Tree is an integrative multi-omics network inference algorithm where the learning of the co-expression modules and the regulator assignment are decoupled and repeated multiple times in order to construct a consensus solution for both. Based on a large dataset of somatic CNA and gene expression profiles from The Cancer Genome Atlas, Lemon-Tree correctly identifies known glioblastoma oncogenes and tumor suppressors as master regulators in the inferred module network [161]. However, matching CNA and gene expression profiles are not always available, and CNAs do not always translate proportionally into altered expression levels due to transcriptional adaptive mechanisms and due to the fact that they exert effects further downstream on core tumor pathways through densely connected gene regulatory networks [163,164]. Therefore, several studies have shown that the effect of genomic alterations in cancer and the search for novel tumor dependencies can be more readily assessed by the inference of gene regulatory networks based on aggregated datasets of gene expression profiles that is specific for the cancer type under study [165-167]. Other information, in the form of regulator binding (e.g., ChIP-sequencing data for transcription factors) or 
multi-omics can be integrated in the process, for a more causal inference of regulatory interactions and a more significant identification of driver genes [168]. ModuleOmics is a statistical framework that simultaneously integrates correlated expression, transcriptional coregulation, protein-protein interactions and mutual exclusivity of mutations and CNAs into highly functionally connected modules enriched with cancer driver genes, outperforming state-of-the-art single omics approaches [169]. Another recently developed tool, Moonlight, also incorporates multi-omics data for the discovery of tumor suppressors, oncogenes and dual role genes in the framework of gene regulatory networks using manually curated expert knowledge and/or machine learning on contrasting normal and tumor samples. While gene expression data are used as the major source of information to detect candidate driver genes, a second layer of evidence from another genome or epigenome data modality e.g., hypermethylation is required to define the candidate drivers as critical cancer driver genes [170].

The transcriptional network-based methods described above have already been successfully applied to NB. Consensus clustering of the TARGET NB patient cohort revealed three molecular subtypes of high-risk NB, consistent with genomic aberrations: $M Y C N$ amplified status and 1p36 deletion for cluster 1,11q deletion for cluster 2 and a mesenchymal signature without any strong genomic aberration association or cluster 3 . Subsequently, master regulators for each of the high-risk subtypes were inferred using the VIPER and ARACNe-AP algorithms based on the enrichment of their transcriptional target genes in the subtype specific gene expression signatures. As an example, a TEAD4-MYCN positive feedback loop emerged as a regulatory driver of the $M Y C N$-amplified high-risk NB subtype [171]. A similar approach was used on gene expression profiling data obtained during murine TH-MYCN-driven NB tumor formation at different time points revealing MEIS2 as candidate NB tumor-initiating factor [147]. In another study, weighted gene co-expression network analysis on publicly available microarray data of 206 NB patients and subsequently association of these modules to chromosomal alterations, indicated that modules involved in nervous system development and cell cycle are highly associated with $M Y C N$ amplification and $1 \mathrm{p}$ deletion, while modules responding to immune system process are associated with MYCN amplification only. BUB1B and CD53, which serve as hub genes in modules responding to cell cycle and immune system processes respectively, are put forward as potential novel drivers. Also from this analysis, CADM1 emerges as a top tumor suppressor gene candidate in 11q-deleted NB [172]. A deep learning auto-encoder framework integrated CNAs and gene expression profiles from the TARGET and SEQC NB cohorts and after filtering for survival dependent genes and/or CNAs, this was combined with k-means clustering to detect two subtypes with significant survival differences [173]. In the context of $\mathrm{NB}$, the gene regulatory networks of the developing neural crest are also worth investigating. Using chromatin and transcriptional profiling of cranial neural crest at population and single cell level, followed by network inference and data integration, the gene regulatory networks of the neural crest was charted [174].

Currently, the potential for adding multiple additional omics layers to copy number, gene expression and methylation is rapidly expanding such as chromatin accessibility (using ATAC-seq), epigenetic status (using ChIP or CUT\&RUN/TAG for chromatin marks) and proteomics [175]. Moreover, single cell technologies are rapidly evolving and offering further opportunities for deep data mining approaches towards more powerful detection of tumor dependencies. Also, approaches are being developed to predict synthetic lethal interactions which may also open further possibilities for target prioritization [176].

\section{Conclusions}

Insights into NB biology and behavior have come a long way ever since the discovery of MYCN amplification. In this review, we have provided a summary of our current insights into copy number driven dependencies. In view of the limited search space for precision oncology drug targets due to the low mutation burden of NBs, further approaches to identify novel druggable vulnerabilities are critically important if we want to increase 
survival rates significantly. Together with current developments of novel approaches to target so-call undruggable targets such as protein degraders [177], we expect a significant number of novel venues to open towards development of less toxic drugs with higher efficacy to eradicate tumor cells. Finally, these developments can be expected to synergize and integrate into emerging novel insights how NB escapes the host immune system and strategies to transform the immunologically cold high-risk NBs into hot tumors that will be more amenable to emerging and new immunotherapeutic treatment regimes.

Author Contributions: Conceptualization, B.D., K.D., V.V. and F.S.; investigation, B.D. and C.V.N., writing-original draft preparation, B.D., K.D., V.V. and F.S.; writing-review and editing, N.V.R., S.V.H., S.R., K.D., K.D.P., B.D.W., C.V.N.; visualization, B.D. and C.V.N., supervision, F.S., project administration, F.S.; funding acquisition, F.S. and K.D.P. All authors have read and agreed to the published version of the manuscript.

Funding: This research was funded by the following funding agencies: the Belgian Foundation against Cancer (2018-087, 2018-125, 2020-112); research project funded by Kom op tegen Kanker (Stand up to Cancer), the Flemish cancer society; the Fund for Scientific Research Flanders (Research projects G087221N, G.0507.12, G049720N and grants 12U4718N, 11C3921N, 11J8313N, 12B5313N, 1514215N, 1197617N); MSKCC's National Cancer Institute Core Grant (P30 CA008748); Fight Kids Cancer, Olivia Fund, ITN Vagabond, ITCC pediatric preclinical POC platform, Villa Joep and Cancer Research Institute Ghent. The following authors B.D.C., K.D., S.V.H. and C.V.N. are supported by an FWO grant (1238420N, 12Q8322N, 3F018519, 12N6917N).

Institutional Review Board Statement: Not applicable.

Informed Consent Statement: Not applicable.

Data Availability Statement: The data presented in this study are openly available in GSE103123 and FigShare at https: / figshare.com/collections /Meta-mining_of_copy_number_profiles_of_highrisk_neuroblastoma_tumors/4169864 (accessed on 20 November 2021) or through the shiny app https:/ / padpuydt.shinyapps.io/check_cn_in_hr_nb/ (accessed on 20 November 2021) [33].

Conflicts of Interest: The authors declare no conflict of interest. The funders had no role in the design of the study; in the collection, analyses, or interpretation of data; in the writing of the manuscript, or in the decision to publish the results.

\section{References}

1. Monclair, T.; Brodeur, G.M.; Ambros, P.F.; Brisse, H.J.; Cecchetto, G.; Holmes, K.; Kaneko, M.; London, W.B.; Matthay, K.K.; Nuchtern, J.G.; et al. The International Neuroblastoma Risk Group (INRG) staging system: An INRG Task Force report. J. Clin. Oncol. Off. J. Am. Soc. Clin. Oncol. 2009, 27, 298-303. [CrossRef]

2. Cohn, S.L.; Pearson, A.D.J.; London, W.B.; Monclair, T.; Ambros, P.F.; Brodeur, G.M.; Faldum, A.; Hero, B.; Iehara, T.; Machin, D.; et al. The International Neuroblastoma Risk Group (INRG) classification system: An INRG Task Force report. J. Clin. Oncol. Off. J. Am. Soc. Clin. Oncol. 2009, 27, 289-297. [CrossRef]

3. Matthay, K.K.; Maris, J.M.; Schleiermacher, G.; Nakagawara, A.; Mackall, C.L.; Diller, L.; Weiss, W.A. Neuroblastoma. Nat. Rev. Dis. Primer 2016, 2, 16078. [CrossRef]

4. Schwab, M.; Varmus, H.E.; Bishop, J.M.; Grzeschik, K.H.; Naylor, S.L.; Sakaguchi, A.Y.; Brodeur, G.; Trent, J. Chromosome localization in normal human cells and neuroblastomas of a gene related to c-myc. Nature 1984, 308, 288-291. [CrossRef]

5. Brodeur, G.M.; Seeger, R.C.; Schwab, M.; Varmus, H.E.; Bishop, J.M. Amplification of N-myc in untreated human neuroblastomas correlates with advanced disease stage. Science 1984, 224, 1121-1124. [CrossRef]

6. Ambros, P.F.; Ambros, I.M.; Strehl, S.; Bauer, S.; Luegmayr, A.; Kovar, H.; Ladenstein, R.; Fink, F.M.; Horcher, E.; Printz, G. Regression and progression in neuroblastoma. Does genetics predict tumour behaviour? Eur. J. Cancer 1995, 31, 510-515. [CrossRef]

7. Janoueix-Lerosey, I.; Lequin, D.; Brugières, L.; Ribeiro, A.; de Pontual, L.; Combaret, V.; Raynal, V.; Puisieux, A.; Schleiermacher, G.; Pierron, G.; et al. Somatic and germline activating mutations of the ALK kinase receptor in neuroblastoma. Nature 2008, 455, 967-970. [CrossRef]

8. Chen, Y.; Takita, J.; Choi, Y.L.; Kato, M.; Ohira, M.; Sanada, M.; Wang, L.; Soda, M.; Kikuchi, A.; Igarashi, T.; et al. Oncogenic mutations of ALK kinase in neuroblastoma. Nature 2008, 455, 971-974. [CrossRef] [PubMed]

9. Carén, H.; Abel, F.; Kogner, P.; Martinsson, T. High incidence of DNA mutations and gene amplifications of the ALK gene in advanced sporadic neuroblastoma tumours. Biochem. J. 2008, 416, 153-159. [CrossRef] [PubMed]

10. Mossé, Y.P.; Laudenslager, M.; Longo, L.; Cole, K.A.; Wood, A.; Attiyeh, E.F.; Laquaglia, M.J.; Sennett, R.; Lynch, J.E.; Perri, P.; et al. Identification of ALK as a major familial neuroblastoma predisposition gene. Nature 2008, 455, 930-935. [CrossRef] 
11. George, R.E.; Sanda, T.; Hanna, M.; Fröhling, S.; Luther, W.; Zhang, J.; Ahn, Y.; Zhou, W.; London, W.B.; McGrady, P.; et al. Activating mutations in ALK provide a therapeutic target in neuroblastoma. Nature 2008, 455, 975-978. [CrossRef]

12. Eleveld, T.F.; Oldridge, D.A.; Bernard, V.; Koster, J.; Colmet Daage, L.; Diskin, S.J.; Schild, L.; Bentahar, N.B.; Bellini, A.; Chicard, M.; et al. Relapsed neuroblastomas show frequent RAS-MAPK pathway mutations. Nat. Genet. 2015, 47, 864-871. [CrossRef]

13. Schramm, A.; Köster, J.; Assenov, Y.; Althoff, K.; Peifer, M.; Mahlow, E.; Odersky, A.; Beisser, D.; Ernst, C.; Henssen, A.G.; et al. Mutational dynamics between primary and relapse neuroblastomas. Nat. Genet. 2015, 47, 872-877. [CrossRef] [PubMed]

14. Schleiermacher, G.; Javanmardi, N.; Bernard, V.; Leroy, Q.; Cappo, J.; Rio Frio, T.; Pierron, G.; Lapouble, E.; Combaret, V.; Speleman, F; et al. Emergence of new ALK mutations at relapse of neuroblastoma. J. Clin. Oncol. Off. J. Am. Soc. Clin. Oncol. 2014, 32, 2727-2734. [CrossRef] [PubMed]

15. Cheung, N.-K.V.; Zhang, J.; Lu, C.; Parker, M.; Bahrami, A.; Tickoo, S.K.; Heguy, A.; Pappo, A.S.; Federico, S.; Dalton, J.; et al. Association of age at diagnosis and genetic mutations in patients with neuroblastoma. JAMA 2012, 307, 1062-1071. [CrossRef]

16. Kurihara, S.; Hiyama, E.; Onitake, Y.; Yamaoka, E.; Hiyama, K. Clinical features of ATRX or DAXX mutated neuroblastoma. J. Pediatr. Surg. 2014, 49, 1835-1838. [CrossRef]

17. Peifer, M.; Hertwig, F.; Roels, F.; Dreidax, D.; Gartlgruber, M.; Menon, R.; Krämer, A.; Roncaioli, J.L.; Sand, F.; Heuckmann, J.M.; et al. Telomerase activation by genomic rearrangements in high-risk neuroblastoma. Nature 2015, 526, 700-704. [CrossRef] [PubMed]

18. Valentijn, L.J.; Koster, J.; Zwijnenburg, D.A.; Hasselt, N.E.; van Sluis, P.; Volckmann, R.; van Noesel, M.M.; George, R.E.; Tytgat, G.A.M.; Molenaar, J.J.; et al. TERT rearrangements are frequent in neuroblastoma and identify aggressive tumors. Nat. Genet. 2015, 47, 1411-1414. [CrossRef] [PubMed]

19. Janoueix-Lerosey, I.; Schleiermacher, G.; Michels, E.; Mosseri, V.; Ribeiro, A.; Lequin, D.; Vermeulen, J.; Couturier, J.; Peuchmaur, M.; Valent, A.; et al. Overall genomic pattern is a predictor of outcome in neuroblastoma. J. Clin. Oncol. Off. J. Am. Soc. Clin. Oncol. 2009, 27, 1026-1033. [CrossRef]

20. Schleiermacher, G.; Janoueix-Lerosey, I.; Ribeiro, A.; Klijanienko, J.; Couturier, J.; Pierron, G.; Mosseri, V.; Valent, A.; Auger, N.; Plantaz, D.; et al. Accumulation of segmental alterations determines progression in neuroblastoma. J. Clin. Oncol. Off. J. Am. Soc. Clin. Oncol. 2010, 28, 3122-3130. [CrossRef]

21. Zeineldin, M.; Federico, S.; Chen, X.; Fan, Y.; Xu, B.; Stewart, E.; Zhou, X.; Jeon, J.; Griffiths, L.; Nguyen, R.; et al. MYCN amplification and ATRX mutations are incompatible in neuroblastoma. Nat. Commun. 2020, 11, 913. [CrossRef]

22. Althoff, K.; Beckers, A.; Bell, E.; Nortmeyer, M.; Thor, T.; Sprüssel, A.; Lindner, S.; De Preter, K.; Florin, A.; Heukamp, L.C.; et al. A Cre-conditional MYCN-driven neuroblastoma mouse model as an improved tool for preclinical studies. Oncogene 2015, 34, 3357-3368. [CrossRef] [PubMed]

23. Brady, S.W.; Liu, Y.; Ma, X.; Gout, A.M.; Hagiwara, K.; Zhou, X.; Wang, J.; Macias, M.; Chen, X.; Easton, J.; et al. Pan-neuroblastoma analysis reveals age- and signature-associated driver alterations. Nat. Commun. 2020, 11, 5183. [CrossRef] [PubMed]

24. Brodeur, G.M.; Green, A.A.; Hayes, F.A.; Williams, K.J.; Williams, D.L.; Tsiatis, A.A. Cytogenetic features of human neuroblastomas and cell lines. Cancer Res. 1981, 41,4678-4686.

25. Maris, J.M.; Guo, C.; Blake, D.; White, P.S.; Hogarty, M.D.; Thompson, P.M.; Rajalingam, V.; Gerbing, R.; Stram, D.O.; Matthay, K.K.; et al. Comprehensive analysis of chromosome 1p deletions in neuroblastoma. Med. Pediatr. Oncol. 2001, 36, 32-36. [CrossRef]

26. White, P.S.; Thompson, P.M.; Seifried, B.A.; Sulman, E.P.; Jensen, S.J.; Guo, C.; Maris, J.M.; Hogarty, M.D.; Allen, C.; Biegel, J.A.; et al. Detailed molecular analysis of 1p36 in neuroblastoma. Med. Pediatr. Oncol. 2001, 36, 37-41. [CrossRef]

27. Carén, H.; Fransson, S.; Ejeskär, K.; Kogner, P.; Martinsson, T. Genetic and epigenetic changes in the common 1p36 deletion in neuroblastoma tumours. Br. J. Cancer 2007, 97, 1416-1424. [CrossRef] [PubMed]

28. Vandesompele, J.; Speleman, F.; Van Roy, N.; Laureys, G.; Brinskchmidt, C.; Christiansen, H.; Lampert, F.; Lastowska, M.; Bown, N.; Pearson, A.; et al. Multicentre analysis of patterns of DNA gains and losses in 204 neuroblastoma tumors: How many genetic subgroups are there? Med. Pediatr. Oncol. 2001, 36, 5-10. [CrossRef]

29. Guo, C.; White, P.S.; Weiss, M.J.; Hogarty, M.D.; Thompson, P.M.; Stram, D.O.; Gerbing, R.; Matthay, K.K.; Seeger, R.C.; Brodeur, G.M.; et al. Allelic deletion at 11q23 is common in MYCN single copy neuroblastomas. Oncogene 1999, 18, 4948-4957. [CrossRef]

30. Plantaz, D.; Vandesompele, J.; Van Roy, N.; Lastowska, M.; Bown, N.; Combaret, V.; Favrot, M.C.; Delattre, O.; Michon, J.; Bénard, J.; et al. Comparative genomic hybridization (CGH) analysis of stage 4 neuroblastoma reveals high frequency of $11 \mathrm{q}$ deletion in tumors lacking MYCN amplification. Int. J. Cancer 2001, 91, 680-686. [CrossRef]

31. Michels, E.; Vandesompele, J.; De Preter, K.; Hoebeeck, J.; Vermeulen, J.; Schramm, A.; Molenaar, J.J.; Menten, B.; Marques, B.; Stallings, R.L.; et al. ArrayCGH-based classification of neuroblastoma into genomic subgroups. Genes. Chromosomes Cancer 2007, 46, 1098-1108. [CrossRef]

32. Schleiermacher, G.; Michon, J.; Huon, I.; d’Enghien, C.D.; Klijanienko, J.; Brisse, H.; Ribeiro, A.; Mosseri, V.; Rubie, H.; Munzer, C.; et al. Chromosomal CGH identifies patients with a higher risk of relapse in neuroblastoma without MYCN amplification. Br. J. Cancer 2007, 97, 238-246. [CrossRef] [PubMed]

33. Depuydt, P.; Koster, J.; Boeva, V.; Hocking, T.D.; Speleman, F.; Schleiermacher, G.; De Preter, K. Meta-mining of copy number profiles of high-risk neuroblastoma tumors. Sci. Data 2018, 5, 180240. [CrossRef] [PubMed]

34. Van Roy, N.; Cheng, N.C.; Laureys, G.; Opdenakker, G.; Versteeg, R.; Speleman, F. Molecular cytogenetic analysis of 1;17 translocations in neuroblastoma. Eur. J. Cancer 1995, 31A, 530-535. [CrossRef] 
35. Bown, N.; Cotterill, S.; Lastowska, M.; O’Neill, S.; Pearson, A.D.; Plantaz, D.; Meddeb, M.; Danglot, G.; Brinkschmidt, C.; Christiansen, H.; et al. Gain of chromosome arm 17q and adverse outcome in patients with neuroblastoma. N. Engl. J. Med. 1999, 340, 1954-1961. [CrossRef] [PubMed]

36. Lastowska, M.; Van Roy, N.; Bown, N.; Speleman, F.; Lunec, J.; Strachan, T.; Pearson, A.D.; Jackson, M.S. Molecular cytogenetic delineation of 17q translocation breakpoints in neuroblastoma cell lines. Genes. Chromosomes Cancer 1998, 23, 116-122. [CrossRef]

37. Vandesompele, J.; Michels, E.; De Preter, K.; Menten, B.; Schramm, A.; Eggert, A.; Ambros, P.F.; Combaret, V.; Francotte, N.; Antonacci, F.; et al. Identification of 2 putative critical segments of $17 \mathrm{q}$ gain in neuroblastoma through integrative genomics. Int. J. Cancer 2008, 122, 1177-1182. [CrossRef]

38. Depuydt, P.; Boeva, V.; Hocking, T.D.; Cannoodt, R.; Ambros, I.M.; Ambros, P.F.; Asgharzadeh, S.; Attiyeh, E.F.; Combaret, V.; Defferrari, R.; et al. Genomic Amplifications and Distal 6q Loss: Novel Markers for Poor Survival in High-risk Neuroblastoma Patients. J. Natl. Cancer Inst. 2018, 110, 1084-1093. [CrossRef]

39. Vandesompele, J.; Baudis, M.; De Preter, K.; Van Roy, N.; Ambros, P.; Bown, N.; Brinkschmidt, C.; Christiansen, H.; Combaret, V.; Lastowska, M.; et al. Unequivocal delineation of clinicogenetic subgroups and development of a new model for improved outcome prediction in neuroblastoma. J. Clin. Oncol. Off. J. Am. Soc. Clin. Oncol. 2005, 23, 2280-2299. [CrossRef]

40. Molenaar, J.J.; Koster, J.; Zwijnenburg, D.A.; van Sluis, P.; Valentijn, L.J.; van der Ploeg, I.; Hamdi, M.; van Nes, J.; Westerman, B.A.; van Arkel, J.; et al. Sequencing of neuroblastoma identifies chromothripsis and defects in neuritogenesis genes. Nature 2012, 483, 589-593. [CrossRef]

41. Helmsauer, K.; Valieva, M.E.; Ali, S.; Chamorro González, R.; Schöpflin, R.; Röefzaad, C.; Bei, Y.; Dorado Garcia, H.; Rodriguez-Fos, E.; Puiggròs, M.; et al. Enhancer hijacking determines extrachromosomal circular MYCN amplicon architecture in neuroblastoma. Nat. Commun. 2020, 11, 5823. [CrossRef] [PubMed]

42. Koche, R.P.; Rodriguez-Fos, E.; Helmsauer, K.; Burkert, M.; MacArthur, I.C.; Maag, J.; Chamorro, R.; Munoz-Perez, N.; Puiggròs, M.; Dorado Garcia, H.; et al. Extrachromosomal circular DNA drives oncogenic genome remodeling in neuroblastoma. Nat. Genet. 2020, 52, 29-34. [CrossRef] [PubMed]

43. Shoshani, O.; Brunner, S.F.; Yaeger, R.; Ly, P.; Nechemia-Arbely, Y.; Kim, D.H.; Fang, R.; Castillon, G.A.; Yu, M.; Li, J.S.Z.; et al. Chromothripsis drives the evolution of gene amplification in cancer. Nature 2021, 591, 137-141. [CrossRef]

44. Kumps, C.; Fieuw, A.; Mestdagh, P.; Menten, B.; Lefever, S.; Pattyn, F.; De Brouwer, S.; Sante, T.; Schulte, J.H.; Schramm, A.; et al Focal DNA copy number changes in neuroblastoma target MYCN regulated genes. PLoS ONE 2013, 8, e52321.

45. De Brouwer, S.; De Preter, K.; Kumps, C.; Zabrocki, P.; Porcu, M.; Westerhout, E.M.; Lakeman, A.; Vandesompele, J.; Hoebeeck, J.; Van Maerken, T.; et al. Meta-analysis of neuroblastomas reveals a skewed ALK mutation spectrum in tumors with MYCN amplification. Clin. Cancer Res. Off. J. Am. Assoc. Cancer Res. 2010, 16, 4353-4362. [CrossRef] [PubMed]

46. Berry, T.; Luther, W.; Bhatnagar, N.; Jamin, Y.; Poon, E.; Sanda, T.; Pei, D.; Sharma, B.; Vetharoy, W.R.; Hallsworth, A.; et al. The ALK(F1174L) mutation potentiates the oncogenic activity of MYCN in neuroblastoma. Cancer Cell 2012, 22, 117-130. [CrossRef]

47. Heukamp, L.C.; Thor, T.; Schramm, A.; De Preter, K.; Kumps, C.; De Wilde, B.; Odersky, A.; Peifer, M.; Lindner, S.; Spruessel, A.; et al. Targeted expression of mutated ALK induces neuroblastoma in transgenic mice. Sci. Transl. Med. 2012, 4, 141ra91. [CrossRef]

48. Zhu, S.; Lee, J.-S.; Guo, F.; Shin, J.; Perez-Atayde, A.R.; Kutok, J.L.; Rodig, S.J.; Neuberg, D.S.; Helman, D.; Feng, H.; et al. Activated ALK collaborates with MYCN in neuroblastoma pathogenesis. Cancer Cell 2012, 21, 362-373. [CrossRef]

49. Unno, K.; Chalmers, Z.R.; Pamarthy, S.; Vatapalli, R.; Rodriguez, Y.; Lysy, B.; Mok, H.; Sagar, V.; Han, H.; Yoo, Y.A.; et al. Activated ALK Cooperates with N-Myc via Wnt/ $\beta$-Catenin Signaling to Induce Neuroendocrine Prostate Cancer. Cancer Res. 2021, 81, 2157-2170. [CrossRef]

50. Weiss, W.A.; Aldape, K.; Mohapatra, G.; Feuerstein, B.G.; Bishop, J.M. Targeted expression of MYCN causes neuroblastoma in transgenic mice. EMBO J. 1997, 16, 2985-2995. [CrossRef]

51. Goldsmith, K.C.; Kayser, K.; Groshen, S.G.; Chioda, M.; Thurm, H.C.; Chen, J.; Peltz, G.; Granger, M.; Maris, J.; Matthay, K.K.; et al. Phase I trial of lorlatinib in patients with ALK-driven refractory or relapsed neuroblastoma: A New Approaches to Neuroblastoma Consortium study. J. Clin. Oncol. 2020, 38, 10504. [CrossRef]

52. Phase 1 Study of Lorlatinib (PF-06463922), an Oral Small Molecule Inhibitor of ALK/ROS1, for Patients with ALK-Driven Relapsed or Refractory Neuroblastoma. Available online: https:/ /www.clinicaltrials.gov/ct2/show /NCT03107988 (accessed on 22 November 2021).

53. Real World Data Collection among Pediatric Neuroblastoma Patients Treated with Lorlatinib through Expanded Access Program. Available online: https: / / www.clinicaltrials.gov / ct2/ show / NCT04753658?term=lorlatinib\&cond=Neuroblastoma\&draw=2\& rank=1 (accessed on 22 November 2021).

54. Molenaar, J.J.; Domingo-Fernández, R.; Ebus, M.E.; Lindner, S.; Koster, J.; Drabek, K.; Mestdagh, P.; van Sluis, P.; Valentijn, L.J.; van Nes, J.; et al. LIN28B induces neuroblastoma and enhances MYCN levels via let-7 suppression. Nat. Genet. 2012, 44, 1199-1206. [CrossRef]

55. Capasso, M.; Diskin, S.J.; Totaro, F.; Longo, L.; De Mariano, M.; Russo, R.; Cimmino, F.; Hakonarson, H.; Tonini, G.P.; Devoto, M.; et al. Replication of GWAS-identified neuroblastoma risk loci strengthens the role of BARD1 and affirms the cumulative effect of genetic variations on disease susceptibility. Carcinogenesis 2013, 34, 605-611. [CrossRef] [PubMed] 
56. Beckers, A.; Van Peer, G.; Carter, D.R.; Gartlgruber, M.; Herrmann, C.; Agarwal, S.; Helsmoortel, H.H.; Althoff, K.; Molenaar, J.J.; Cheung, B.B.; et al. MYCN-driven regulatory mechanisms controlling LIN28B in neuroblastoma. Cancer Lett. 2015, 366, 123-132. [CrossRef]

57. Chen, D.; Cox, J.; Annam, J.; Weingart, M.; Essien, G.; Rathi, K.S.; Rokita, J.L.; Khurana, P.; Cuya, S.M.; Bosse, K.R.; et al. LIN28B promotes neuroblastoma metastasis and regulates PDZ binding kinase. Neoplasia 2020, 22, 231-241. [CrossRef]

58. Schnepp, R.W.; Khurana, P.; Attiyeh, E.F.; Raman, P.; Chodosh, S.E.; Oldridge, D.A.; Gagliardi, M.E.; Conkrite, K.L.; Asgharzadeh, S.; Seeger, R.C.; et al. A LIN28B-RAN-AURKA Signaling Network Promotes Neuroblastoma Tumorigenesis. Cancer Cell 2015, 28, 599-609. [CrossRef] [PubMed]

59. Tao, T.; Shi, H.; Mariani, L.; Abraham, B.J.; Durbin, A.D.; Zimmerman, M.W.; Powers, J.T.; Missios, P.; Ross, K.N.; Perez-Atayde, A.R.; et al. LIN28B regulates transcription and potentiates MYCN-induced neuroblastoma through binding to ZNF143 at target gene promotors. Proc. Natl. Acad. Sci. USA 2020, 117, 16516-16526. [CrossRef]

60. He, L.; Thomson, J.M.; Hemann, M.T.; Hernando-Monge, E.; Mu, D.; Goodson, S.; Powers, S.; Cordon-Cardo, C.; Lowe, S.W.; Hannon, G.J.; et al. A microRNA polycistron as a potential human oncogene. Nature 2005, 435, 828-833. [CrossRef] [PubMed]

61. Castellano, L.; Giamas, G.; Jacob, J.; Coombes, R.C.; Lucchesi, W.; Thiruchelvam, P.; Barton, G.; Jiao, L.R.; Wait, R.; Waxman, J.; et al. The estrogen receptor-alpha-induced microRNA signature regulates itself and its transcriptional response. Proc. Natl. Acad. Sci. USA 2009, 106, 15732-15737. [CrossRef]

62. Hayashita, Y.; Osada, H.; Tatematsu, Y.; Yamada, H.; Yanagisawa, K.; Tomida, S.; Yatabe, Y.; Kawahara, K.; Sekido, Y.; Takahashi, T. A polycistronic microRNA cluster, miR-17-92, is overexpressed in human lung cancers and enhances cell proliferation. Cancer Res. 2005, 65, 9628-9632. [CrossRef] [PubMed]

63. Fontana, L.; Fiori, M.E.; Albini, S.; Cifaldi, L.; Giovinazzi, S.; Forloni, M.; Boldrini, R.; Donfrancesco, A.; Federici, V.; Giacomini, P.; et al. Antagomir-17-5p abolishes the growth of therapy-resistant neuroblastoma through p21 and BIM. PLoS ONE 2008, 3, e2236. [CrossRef]

64. Dews, M.; Fox, J.L.; Hultine, S.; Sundaram, P.; Wang, W.; Liu, Y.Y.; Furth, E.; Enders, G.H.; El-Deiry, W.; Schelter, J.M.; et al. The myc-miR-17 92 axis blunts TGF $\{$ beta\} signaling and production of multiple TGF $\{$ beta\}-dependent antiangiogenic factors. Cancer Res. 2010, 70, 8233-8246. [CrossRef] [PubMed]

65. Mestdagh, P.; Boström, A.-K.; Impens, F.; Fredlund, E.; Van Peer, G.; De Antonellis, P.; von Stedingk, K.; Ghesquière, B.; Schulte, S.; Dews, M.; et al. The miR-17-92 microRNA cluster regulates multiple components of the TGF- $\beta$ pathway in neuroblastoma. Mol. Cell 2010, 40, 762-773. [CrossRef] [PubMed]

66. Han, Y.-C.; Vidigal, J.A.; Mu, P.; Yao, E.; Singh, I.; González, A.J.; Concepcion, C.P.; Bonetti, C.; Ogrodowski, P.; Carver, B.; et al. An allelic series of miR-17 92-mutant mice uncovers functional specialization and cooperation among members of a microRNA polycistron. Nat. Genet. 2015, 47, 766-775. [CrossRef] [PubMed]

67. Mestdagh, P.; Fredlund, E.; Pattyn, F.; Schulte, J.H.; Muth, D.; Vermeulen, J.; Kumps, C.; Schlierf, S.; De Preter, K.; Van Roy, N.; et al. MYCN/c-MYC-induced microRNAs repress coding gene networks associated with poor outcome in MYCN/c-MYC-activated tumors. Oncogene 2010, 29, 1394-1404. [CrossRef]

68. Nagy, Z.; Seneviratne, J.A.; Kanikevich, M.; Chang, W.; Mayoh, C.; Venkat, P.; Du, Y.; Jiang, C.; Salib, A.; Koach, J.; et al. An ALYREF-MYCN coactivator complex drives neuroblastoma tumorigenesis through effects on USP3 and MYCN stability. Nat. Commun. 2021, 12, 1881. [CrossRef]

69. Van Roy, N.; Vandesompele, J.; Menten, B.; Nilsson, H.; De Smet, E.; Rocchi, M.; De Paepe, A.; Påhlman, S.; Speleman, F. Translocation-excision-deletion-amplification mechanism leading to nonsyntenic coamplification of MYC and ATBF1. Genes. Chromosomes Cancer 2006, 45, 107-117. [CrossRef]

70. Zimmerman, M.W.; Liu, Y.; He, S.; Durbin, A.D.; Abraham, B.J.; Easton, J.; Shao, Y.; Xu, B.; Zhu, S.; Zhang, X.; et al. MYC Drives a Subset of High-Risk Pediatric Neuroblastomas and Is Activated through Mechanisms Including Enhancer Hijacking and Focal Enhancer Amplification. Cancer Discov. 2018, 8, 320-335. [CrossRef]

71. Van Roy, N.; Forus, A.; Myklebost, O.; Cheng, N.C.; Versteeg, R.; Speleman, F. Identification of two distinct chromosome 12-derived amplification units in neuroblastoma cell line NGP. Cancer Genet. Cytogenet. 1995, 82, 151-154.

72. Kranenburg, O.; Scharnhorst, V.; Van der Eb, A.J.; Zantema, A. Inhibition of cyclin-dependent kinase activity triggers neuronal differentiation of mouse neuroblastoma cells. J. Cell Biol. 1995, 131, 227-234. [CrossRef]

73. Gogolin, S.; Ehemann, V.; Becker, G.; Brueckner, L.M.; Dreidax, D.; Bannert, S.; Nolte, I.; Savelyeva, L.; Bell, E.; Westermann, F. CDK4 inhibition restores $\mathrm{G}_{1}-\mathrm{S}$ arrest in MYCN-amplified neuroblastoma cells in the context of doxorubicin-induced DNA damage. Cell Cycle 2013, 12, 1091-1104. [CrossRef]

74. Moreno, L.; Caron, H.; Geoerger, B.; Eggert, A.; Schleiermacher, G.; Brock, P.; Valteau-Couanet, D.; Chesler, L.; Schulte, J.H.; De Preter, K.; et al. Accelerating drug development for neuroblastoma-New Drug Development Strategy: An Innovative Therapies for Children with Cancer, European Network for Cancer Research in Children and Adolescents and International Society of Paediatric Oncology Europe Neuroblastoma project. Expert Opin. Drug Discov. 2017, 12, 801-811. [PubMed]

75. Rihani, A.; Vandesompele, J.; Speleman, F.; Van Maerken, T. Inhibition of CDK4/6 as a novel therapeutic option for neuroblastoma. Cancer Cell Int. 2015, 15, 76. [CrossRef] [PubMed]

76. Rader, J.; Russell, M.R.; Hart, L.S.; Nakazawa, M.S.; Belcastro, L.T.; Martinez, D.; Li, Y.; Carpenter, E.L.; Attiyeh, E.F.; Diskin, S.J.; et al. Dual CDK4/CDK6 inhibition induces cell-cycle arrest and senescence in neuroblastoma. Clin. Cancer Res. Off. J. Am. Assoc. Cancer Res. 2013, 19, 6173-6182. [CrossRef] [PubMed] 
77. Geoerger, B.; Bourdeaut, F.; DuBois, S.G.; Fischer, M.; Geller, J.I.; Gottardo, N.G.; Marabelle, A.; Pearson, A.D.J.; Modak, S.; Cash, T.; et al. A Phase I Study of the CDK4/6 Inhibitor Ribociclib (LEE011) in Pediatric Patients with Malignant Rhabdoid Tumors, Neuroblastoma, and Other Solid Tumors. Clin. Cancer Res. Off. J. Am. Assoc. Cancer Res. 2017, 23, 2433-2441. [CrossRef]

78. Wood, A.C.; Krytska, K.; Ryles, H.T.; Infarinato, N.R.; Sano, R.; Hansel, T.D.; Hart, L.S.; King, F.J.; Smith, T.R.; Ainscow, E.; et al. Dual ALK and CDK4/6 Inhibition Demonstrates Synergy against Neuroblastoma. Clin. Cancer Res. 2017, 23, $2856-2868$. [CrossRef] [PubMed]

79. Hart, L.S.; Rader, J.; Raman, P.; Batra, V.; Russell, M.R.; Tsang, M.; Gagliardi, M.; Chen, L.; Martinez, D.; Li, Y.; et al. Preclinical Therapeutic Synergy of MEK1/2 and CDK4/6 Inhibition in Neuroblastoma. Clin. Cancer Res. Off. J. Am. Assoc. Cancer Res. 2017, 23, 1785-1796. [CrossRef]

80. Schubert, N.A.; Schild, L.; van Oirschot, S.; Keller, K.M.; Alles, L.K.; Vernooij, L.; Nulle, M.E.; Dolman, M.E.M.; van den Boogaard, M.L.; Molenaar, J.J. Combined targeting of the p53 and pRb pathway in neuroblastoma does not lead to synergistic responses. Eur. J. Cancer 2021, 142, 1-9. [CrossRef]

81. Molenaar, J.J.; Ebus, M.E.; Koster, J.; van Sluis, P.; van Noesel, C.J.M.; Versteeg, R.; Caron, H.N. Cyclin D1 and CDK4 Activity Contribute to the Undifferentiated Phenotype in Neuroblastoma. Cancer Res. 2008, 68, 2599-2609. [CrossRef]

82. Meitinger, F.; Ohta, M.; Lee, K.-Y.; Watanabe, S.; Davis, R.L.; Anzola, J.V.; Kabeche, R.; Jenkins, D.A.; Shiau, A.K.; Desai, A.; et al. TRIM37 controls cancer-specific vulnerability to PLK4 inhibition. Nature 2020, 585, 440-446. [CrossRef]

83. Keshelava, N.; Zuo, J.J.; Chen, P.; Waidyaratne, S.N.; Luna, M.C.; Gomer, C.J.; Triche, T.J.; Reynolds, C.P. Loss of p53 function confers high-level multidrug resistance in neuroblastoma cell lines. Cancer Res. 2001, 61, 6185-6193. [PubMed]

84. Corvi, R.; Savelyeva, L.; Breit, S.; Wenzel, A.; Handgretinger, R.; Barak, J.; Oren, M.; Amler, L.; Schwab, M. Non-syntenic amplification of MDM2 and MYCN in human neuroblastoma. Oncogene 1995, 10, 1081-1086. [PubMed]

85. Corvi, R.; Savelyeva, L.; Amler, L.; Handgretinger, R.; Schwab, M. Cytogenetic evolution of MYCN and MDM2 amplification in the neuroblastoma LS tumour and its cell line. Eur. J. Cancer 1995, 31A, 520-523. [CrossRef]

86. Carr-Wilkinson, J.; O’Toole, K.; Wood, K.M.; Challen, C.C.; Baker, A.G.; Board, J.R.; Evans, L.; Cole, M.; Cheung, N.-K.V.; Boos, J.; et al. High Frequency of p53/MDM2/p14ARF Pathway Abnormalities in Relapsed Neuroblastoma. Clin. Cancer Res. 2010, 16, 1108-1118. [CrossRef]

87. Chen, Z.; Lin, Y.; Barbieri, E.; Burlingame, S.; Hicks, J.; Ludwig, A.; Shohet, J.M. Mdm2 deficiency suppresses MYCN-Driven neuroblastoma tumorigenesis in vivo. Neoplasia 2009, 11, 753-762. [CrossRef]

88. Van Maerken, T.; Vandesompele, J.; Rihani, A.; De Paepe, A.; Speleman, F. Escape from p53-mediated tumor surveillance in neuroblastoma: Switching off the p14ARF-MDM2-p53 axis. Cell Death Differ. 2009, 16, 1563-1572. [CrossRef]

89. Carr, J.; Bell, E.; Pearson, A.D.J.; Kees, U.R.; Beris, H.; Lunec, J.; Tweddle, D.A. Increased frequency of aberrations in the p53/MDM2/p14(ARF) pathway in neuroblastoma cell lines established at relapse. Cancer Res. 2006, 66, 2138-2145. [CrossRef] [PubMed]

90. Dreidax, D.; Gogolin, S.; Schroeder, C.; Muth, D.; Brueckner, L.M.; Hess, E.M.; Zapatka, M.; Theißen, J.; Fischer, M.; Ehemann, V.; et al. Low p14ARF expression in neuroblastoma cells is associated with repressed histone mark status, and enforced expression induces growth arrest and apoptosis. Hum. Mol. Genet. 2013, 22, 1735-1745. [CrossRef] [PubMed]

91. Slack, A.; Chen, Z.; Tonelli, R.; Pule, M.; Hunt, L.; Pession, A.; Shohet, J.M. The p53 regulatory gene MDM2 is a direct transcriptional target of MYCN in neuroblastoma. Proc. Natl. Acad. Sci. USA 2005, 102, 731-736. [CrossRef]

92. Slack, A.D.; Chen, Z.; Ludwig, A.D.; Hicks, J.; Shohet, J.M. MYCN-directed centrosome amplification requires MDM2-mediated suppression of p53 activity in neuroblastoma cells. Cancer Res. 2007, 67, 2448-2455. [CrossRef]

93. He, J.; Gu, L.; Zhang, H.; Zhou, M. Crosstalk between MYCN and MDM2-p53 signal pathways regulates tumor cell growth and apoptosis in neuroblastoma. Cell Cycle 2011, 10, 2994-3002. [CrossRef] [PubMed]

94. Gu, L.; Zhang, H.; He, J.; Li, J.; Huang, M.; Zhou, M. MDM2 regulates MYCN mRNA stabilization and translation in human neuroblastoma cells. Oncogene 2012, 31, 1342-1353. [CrossRef]

95. Agarwal, S.; Milazzo, G.; Rajapakshe, K.; Bernardi, R.; Chen, Z.; Barbieri, E.; Koster, J.; Perini, G.; Coarfa, C.; Shohet, J.M. MYCN acts as a direct co-regulator of p53 in MYCN amplified neuroblastoma. Oncotarget 2018, 9, 20323-20338. [CrossRef] [PubMed]

96. Vassilev, L.T.; Vu, B.T.; Graves, B.; Carvajal, D.; Podlaski, F.; Filipovic, Z.; Kong, N.; Kammlott, U.; Lukacs, C.; Klein, C.; et al. In vivo activation of the p53 pathway by small-molecule antagonists of MDM2. Science 2004, 303, 844-848. [CrossRef]

97. Van Maerken, T.; Speleman, F.; Vermeulen, J.; Lambertz, I.; De Clercq, S.; De Smet, E.; Yigit, N.; Coppens, V.; Philippé, J.; De Paepe, A.; et al. Small-molecule MDM2 antagonists as a new therapy concept for neuroblastoma. Cancer Res. 2006, 66, 9646-9655. [CrossRef]

98. Barbieri, E.; Mehta, P.; Chen, Z.; Zhang, L.; Slack, A.; Berg, S.; Shohet, J.M. MDM2 inhibition sensitizes neuroblastoma to chemotherapy-induced apoptotic cell death. Mol. Cancer Ther. 2006, 5, 2358-2365. [CrossRef] [PubMed]

99. Michaelis, M.; Rothweiler, F.; Klassert, D.; von Deimling, A.; Weber, K.; Fehse, B.; Kammerer, B.; Doerr, H.W.; Cinatl, J. Reversal of P-glycoprotein-mediated multidrug resistance by the murine double minute 2 antagonist nutlin-3. Cancer Res. 2009, 69, 416-421. [CrossRef]

100. Wang, W.; Wang, X.; Rajaei, M.; Youn, J.Y.; Zafar, A.; Deokar, H.; Buolamwini, J.K.; Yang, J.; Foster, J.H.; Zhou, J.; et al. Targeting MDM2 for Neuroblastoma Therapy: In Vitro and In Vivo Anticancer Activity and Mechanism of Action. Cancers 2020, 12, 3651. [CrossRef] [PubMed] 
101. Zafar, A.; Wang, W.; Liu, G.; Xian, W.; McKeon, F.; Zhou, J.; Zhang, R. Targeting the p53-MDM2 pathway for neuroblastoma therapy: Rays of hope. Cancer Lett. 2021, 496, 16-29. [CrossRef] [PubMed]

102. Adida, C.; Berrebi, D.; Peuchmaur, M.; Reyes-Mugica, M.; Altieri, D.C. Anti-apoptosis gene, survivin, and prognosis of neuroblastoma. Lancet 1998, 351, 882-883. [CrossRef]

103. Islam, A.; Kageyama, H.; Takada, N.; Kawamoto, T.; Takayasu, H.; Isogai, E.; Ohira, M.; Hashizume, K.; Kobayashi, H.; Kaneko, Y.; et al. High expression of Survivin, mapped to $17 \mathrm{q} 25$, is significantly associated with poor prognostic factors and promotes cell survival in human neuroblastoma. Oncogene 2000, 19, 617-623. [CrossRef]

104. Wheatley, S.P.; Altieri, D.C. Survivin at a glance. J. Cell Sci. 2019, 132, jcs223826. [CrossRef]

105. Hipp, N.I.; Christner, L.; Wirth, T.; Mueller-Klieser, W.; Walenta, S.; Schröck, E.; Debatin, K.-M.; Beltinger, C. MYCN and survivin cooperatively contribute to malignant transformation of fibroblasts. Carcinogenesis 2014, 35, 479-488. [CrossRef] [PubMed]

106. Michaelis, M.; Voges, Y.; Rothweiler, F.; Weipert, F.; Zia-Ahmad, A.; Cinatl, J.; von Deimling, A.; Westermann, F.; Rödel, F.; Wass, M.N.; et al. Testing of the Survivin Suppressant YM155 in a Large Panel of Drug-Resistant Neuroblastoma Cell Lines. Cancers 2020, 12, 577. [CrossRef] [PubMed]

107. Gholizadeh, S.; Dolman, E.M.; Wieriks, R.; Sparidans, R.W.; Hennink, W.E.; Kok, R.J. Anti-GD2 Immunoliposomes for Targeted Delivery of the Survivin Inhibitor Sepantronium Bromide (YM155) to Neuroblastoma Tumor Cells. Pharm. Res. 2018, 35, 85. [CrossRef]

108. Durbin, A.D.; Zimmerman, M.W.; Dharia, N.V.; Abraham, B.J.; Iniguez, A.B.; Weichert-Leahey, N.; He, S.; Krill-Burger, J.M.; Root, D.E.; Vazquez, F.; et al. Selective gene dependencies in MYCN-amplified neuroblastoma include the core transcriptional regulatory circuitry. Nat. Genet. 2018, 50, 1240-1246. [CrossRef] [PubMed]

109. Decaesteker, B.; Denecker, G.; Van Neste, C.; Dolman, E.M.; Van Loocke, W.; Gartlgruber, M.; Nunes, C.; De Vloed, F.; Depuydt, P.; Verboom, K.; et al. TBX2 is a neuroblastoma core regulatory circuitry component enhancing MYCN/FOXM1 reactivation of DREAM targets. Nat. Commun. 2018, 9, 4866. [CrossRef] [PubMed]

110. Wong, M.; Sun, Y.; Xi, Z.; Milazzo, G.; Poulos, R.C.; Bartenhagen, C.; Bell, J.L.; Mayoh, C.; Ho, N.; Tee, A.E.; et al. JMJD6 is a tumorigenic factor and therapeutic target in neuroblastoma. Nat. Commun. 2019, 10, 3319. [CrossRef]

111. Decaesteker, B.; Louwagie, A.; Loontiens, S.; Vloed, F.D.; Roels, J.; Vanhauwaert, S.; Brouwer, S.D.; Sanders, E.; Denecker, G.; D'haene, E.; et al. SOX11 Is a Lineage-Dependency Factor and Master Epigenetic Regulator in Neuroblastoma. bioRxiv 2020. [CrossRef]

112. Afanasyeva, E.A.; Gartlgruber, M.; Ryl, T.; Decaesteker, B.; Denecker, G.; Mönke, G.; Toprak, U.H.; Florez, A.; Torkov, A.; Dreidax, D.; et al. Kalirin-RAC controls nucleokinetic migration in ADRN-type neuroblastoma. Life Sci. Alliance 2021, 4, e201900332. [CrossRef]

113. Mondal, T.; Juvvuna, P.K.; Kirkeby, A.; Mitra, S.; Kosalai, S.T.; Traxler, L.; Hertwig, F.; Wernig-Zorc, S.; Miranda, C.; Deland, L.; et al. Sense-Antisense lncRNA Pair Encoded by Locus 6p22.3 Determines Neuroblastoma Susceptibility via the USP36-CHD7-SOX9 Regulatory Axis. Cancer Cell 2018, 33, 417-434.e7. [CrossRef] [PubMed]

114. Yao, H.; Hannum, D.F.; Zhai, Y.; Hill, S.F.; Ricardo, D.; Lou, W.; Skidmore, J.M.; Sanchez, G.; Saiakhova, A.; Bielas, S.L.; et al. $\mathrm{CHD7}$ promotes neural progenitor differentiation in embryonic stem cells via altered chromatin accessibility and nascent gene expression. Sci. Rep. 2020, 10, 17445. [CrossRef]

115. Yang, C.-L.; Serra-Roma, A.; Gualandi, M.; Bodmer, N.; Niggli, F.; Schulte, J.H.; Bode, P.K.; Shakhova, O. Lineage-restricted sympathoadrenal progenitors confer neuroblastoma origin and its tumorigenicity. Oncotarget 2020, 11, 2357-2371. [CrossRef] [PubMed]

116. Saito-Ohara, F.; Imoto, I.; Inoue, J.; Hosoi, H.; Nakagawara, A.; Sugimoto, T.; Inazawa, J. PPM1D is a potential target for 17q gain in neuroblastoma. Cancer Res. 2003, 63, 1876-1883. [PubMed]

117. Milosevic, J.; Fransson, S.; Gulyas, M.; Gallo-Oller, G.; Olsen, T.K.; Treis, D.; Wickström, M.; Elfman, L.H.; Sveinbjornsson, B.; Hertwig, F.; et al. PPM1D Is a Neuroblastoma Oncogene and Therapeutic Target in Childhood Neural Tumors. bioRxiv 2020. [CrossRef]

118. Herold, S.; Kalb, J.; Büchel, G.; Ade, C.P.; Baluapuri, A.; Xu, J.; Koster, J.; Solvie, D.; Carstensen, A.; Klotz, C.; et al. Recruitment of BRCA1 limits MYCN-driven accumulation of stalled RNA polymerase. Nature 2019, 567, 545-549. [CrossRef]

119. Blazek, D.; Kohoutek, J.; Bartholomeeusen, K.; Johansen, E.; Hulinkova, P.; Luo, Z.; Cimermancic, P.; Ule, J.; Peterlin, B.M. The Cyclin K/Cdk12 complex maintains genomic stability via regulation of expression of DNA damage response genes. Genes Dev. 2011, 25, 2158-2172. [CrossRef]

120. Krajewska, M.; Dries, R.; Grassetti, A.V.; Dust, S.; Gao, Y.; Huang, H.; Sharma, B.; Day, D.S.; Kwiatkowski, N.; Pomaville, M.; et al. CDK12 loss in cancer cells affects DNA damage response genes through premature cleavage and polyadenylation. Nat. Commun. 2019, 10, 1757. [CrossRef] [PubMed]

121. Zhang, T.; Kwiatkowski, N.; Olson, C.M.; Dixon-Clarke, S.E.; Abraham, B.J.; Greifenberg, A.K.; Ficarro, S.B.; Elkins, J.M.; Liang, Y.; Hannett, N.M.; et al. Covalent targeting of remote cysteine residues to develop CDK12 and CDK13 inhibitors. Nat. Chem. Biol. 2016, 12, 876-884. [CrossRef] [PubMed]

122. Johnson, S.F.; Cruz, C.; Greifenberg, A.K.; Dust, S.; Stover, D.G.; Chi, D.; Primack, B.; Cao, S.; Bernhardy, A.J.; Coulson, R.; et al. CDK12 Inhibition Reverses De Novo and Acquired PARP Inhibitor Resistance in BRCA Wild-Type and Mutated Models of Triple-Negative Breast Cancer. Cell Rep. 2016, 17, 2367-2381. [CrossRef] 
123. Jiang, B.; Jiang, J.; Kaltheuner, I.H.; Iniguez, A.B.; Anand, K.; Ferguson, F.M.; Ficarro, S.B.; Seong, B.K.A.; Greifenberg, A.K.; Dust, S.; et al. Structure-activity relationship study of THZ531 derivatives enables the discovery of BSJ-01-175 as a dual CDK12/13 covalent inhibitor with efficacy in Ewing sarcoma. Eur. J. Med. Chem. 2021, 221, 113481. [CrossRef]

124. Mayor-Ruiz, C.; Bauer, S.; Brand, M.; Kozicka, Z.; Siklos, M.; Imrichova, H.; Kaltheuner, I.H.; Hahn, E.; Seiler, K.; Koren, A.; et al. Rational discovery of molecular glue degraders via scalable chemical profiling. Nat. Chem. Biol. 2020, 16, 1199-1207. [CrossRef]

125. Nunes, C.; Depestel, L.; Mus, L.; Keller, K.; Delhaye, L.; Louwagie, A.; Rishfi, M.; Dolman, E.; Olexiouk, V.; Bartenhagen, C.; et al. RRM2 Is a Target for Synthetic Lethal Interactions with Replication Stress Checkpoint Addiction in High-Risk Neuroblastoma. bioRxiv 2020. [CrossRef]

126. Mazzu, Y.Z.; Armenia, J.; Chakraborty, G.; Yoshikawa, Y.; Coggins, S.A.; Nandakumar, S.; Gerke, T.A.; Pomerantz, M.M.; Qiu, X.; Zhao, H.; et al. A Novel Mechanism Driving Poor-Prognosis Prostate Cancer: Overexpression of the DNA Repair Gene, Ribonucleotide Reductase Small Subunit M2 (RRM2). Clin. Cancer Res. Off. J. Am. Assoc. Cancer Res. 2019, 25, 4480-4492. [CrossRef]

127. Fatkhutdinov, N.; Sproesser, K.; Krepler, C.; Liu, Q.; Brafford, P.A.; Herlyn, M.; Aird, K.M.; Zhang, R. Targeting RRM2 and Mutant BRAF Is a Novel Combinatorial Strategy for Melanoma. Mol. Cancer Res. MCR 2016, 14, 767-775. [CrossRef]

128. Ohmura, S.; Marchetto, A.; Orth, M.F.; Li, J.; Jabar, S.; Ranft, A.; Vinca, E.; Ceranski, K.; Carreño-Gonzalez, M.J.; Romero-Pérez, L.; et al. Translational evidence for RRM2 as a prognostic biomarker and therapeutic target in Ewing sarcoma. Mol. Cancer 2021, 20, 97. [CrossRef] [PubMed]

129. Lambertz, I.; Kumps, C.; Claeys, S.; Lindner, S.; Beckers, A.; Janssens, E.; Carter, D.R.; Cazes, A.; Cheung, B.B.; De Mariano, M.; et al. Upregulation of MAPK Negative Feedback Regulators and RET in Mutant ALK Neuroblastoma: Implications for Targeted Treatment. Clin. Cancer Res. Off. J. Am. Assoc. Cancer Res. 2015, 21, 3327-3339. [CrossRef] [PubMed]

130. Mus, L.M.; Lambertz, I.; Claeys, S.; Kumps, C.; Van Loocke, W.; Van Neste, C.; Umapathy, G.; Vaapil, M.; Bartenhagen, C.; Laureys, G.; et al. The ETS transcription factor ETV5 is a target of activated ALK in neuroblastoma contributing to increased tumour aggressiveness. Sci. Rep. 2020, 10, 218. [CrossRef]

131. Claeys, S.; Denecker, G.; Durinck, K.; Decaesteker, B.; Mus, L.M.; Loontiens, S.; Vanhauwaert, S.; Althoff, K.; Wigerup, C.; Bexell, D.; et al. ALK positively regulates MYCN activity through repression of HBP1 expression. Oncogene 2019, 38, $2690-2705$. [CrossRef]

132. Emdal, K.B.; Pedersen, A.-K.; Bekker-Jensen, D.B.; Lundby, A.; Claeys, S.; De Preter, K.; Speleman, F.; Francavilla, C.; Olsen, J.V. Integrated proximal proteomics reveals IRS2 as a determinant of cell survival in ALK-driven neuroblastoma. Sci. Signal. 2018, 11, eaap9752. [CrossRef] [PubMed]

133. Bedoya-Reina, O.C.; Li, W.; Arceo, M.; Plescher, M.; Bullova, P.; Pui, H.; Kaucka, M.; Kharchenko, P.; Martinsson, T.; Holmberg, J.; et al. Single-nuclei transcriptomes from human adrenal gland reveal distinct cellular identities of low and high-risk neuroblastoma tumors. Nat. Commun. 2021, 12, 5309. [CrossRef] [PubMed]

134. Borenäs, M.; Umapathy, G.; Lai, W.-Y.; Lind, D.E.; Witek, B.; Guan, J.; Mendoza-Garcia, P.; Masudi, T.; Claeys, A.; Chuang, T.-P.; et al. ALK ligand ALKAL2 potentiates MYCN-driven neuroblastoma in the absence of ALK mutation. EMBO J. 2021, 40, e105784. [CrossRef]

135. Boeva, V.; Louis-Brennetot, C.; Peltier, A.; Durand, S.; Pierre-Eugène, C.; Raynal, V.; Etchevers, H.C.; Thomas, S.; Lermine, A.; Daudigeos-Dubus, E.; et al. Heterogeneity of neuroblastoma cell identity defined by transcriptional circuitries. Nat. Genet. 2017, 49, 1408-1413. [CrossRef]

136. van Groningen, T.; Koster, J.; Valentijn, L.J.; Zwijnenburg, D.A.; Akogul, N.; Hasselt, N.E.; Broekmans, M.; Haneveld, F.; Nowakowska, N.E.; Bras, J.; et al. Neuroblastoma is composed of two super-enhancer-associated differentiation states. Nat. Genet. 2017, 49, 1261-1266. [CrossRef] [PubMed]

137. Molenaar, J.J.; Koster, J.; Ebus, M.E.; van Sluis, P.; Westerhout, E.M.; de Preter, K.; Gisselsson, D.; Øra, I.; Speleman, F.; Caron, H.N.; et al. Copy number defects of G1-Cell cycle genes in neuroblastoma are frequent and correlate with high expression of E2F target genes and a poor prognosis. Genes. Chromosomes Cancer 2012, 51, 10-19. [CrossRef] [PubMed]

138. Waber, P.G.; Chen, J.; Nisen, P.D. Infrequency of MDM2 gene amplification in pediatric solid tumors and lack of association with p53 mutations in adult squamous cell carcinomas. Cancer Res. 1993, 53, 6028-6030. [PubMed]

139. Ackermann, S.; Cartolano, M.; Hero, B.; Welte, A.; Kahlert, Y.; Roderwieser, A.; Bartenhagen, C.; Walter, E.; Gecht, J.; Kerschke, L.; et al. A mechanistic classification of clinical phenotypes in neuroblastoma. Science 2018, 362, 1165-1170. [CrossRef]

140. Velculescu, V.E.; Madden, S.L.; Zhang, L.; Lash, A.E.; Yu, J.; Rago, C.; Lal, A.; Wang, C.J.; Beaudry, G.A.; Ciriello, K.M.; et al. Analysis of human transcriptomes. Nat. Genet. 1999, 23, 387-388. [CrossRef]

141. Qi, J.; Dong, Z.; Liu, J.; Peery, R.C.; Zhang, S.; Liu, J.-Y.; Zhang, J.-T. Effective Targeting of the Survivin Dimerization Interface with Small-Molecule Inhibitors. Cancer Res. 2016, 76, 453-462. [CrossRef]

142. Berezov, A.; Cai, Z.; Freudenberg, J.A.; Zhang, H.; Cheng, X.; Thompson, T.; Murali, R.; Greene, M.I.; Wang, Q. Disabling the mitotic spindle and tumor growth by targeting a cavity-induced allosteric site of survivin. Oncogene 2012, 31, 1938-1948. [CrossRef]

143. Fenstermaker, R.A.; Figel, S.A.; Qiu, J.; Barone, T.A.; Dharma, S.S.; Winograd, E.K.; Galbo, P.M.; Wiltsie, L.M.; Ciesielski, M.J. Survivin Monoclonal Antibodies Detect Survivin Cell Surface Expression and Inhibit Tumor Growth In Vivo. Clin. Cancer Res. Off. J. Am. Assoc. Cancer Res. 2018, 24, 2642-2652. [CrossRef] 
144. Li, Z.; Zhang, L.; Tang, C.; Yin, C. Co-Delivery of Doxorubicin and Survivin shRNA-Expressing Plasmid Via MicroenvironmentResponsive Dendritic Mesoporous Silica Nanoparticles for Synergistic Cancer Therapy. Pharm. Res. 2017, 34, $2829-2841$. [CrossRef]

145. Nucleosome-Bound SOX2 and SOX11 Structures Elucidate Pioneer Factor Function I Nature. Available online: https://www. nature.com/articles/s41586-020-2195-y (accessed on 4 October 2021).

146. Richter, M.; Dayaram, T.; Gilmartin, A.G.; Ganji, G.; Pemmasani, S.K.; Van Der Key, H.; Shohet, J.M.; Donehower, L.A.; Kumar, R. WIP1 Phosphatase as a Potential Therapeutic Target in Neuroblastoma. PLoS ONE 2015, 10, e0115635. [CrossRef] [PubMed]

147. De Wyn, J.; Zimmerman, M.W.; Weichert-Leahey, N.; Nunes, C.; Cheung, B.B.; Abraham, B.J.; Beckers, A.; Volders, P.-J.; Decaesteker, B.; Carter, D.R.; et al. MEIS2 Is an Adrenergic Core Regulatory Transcription Factor Involved in Early Initiation of TH-MYCN-Driven Neuroblastoma Formation. Cancers 2021, 13, 4783. [CrossRef] [PubMed]

148. Burkhart, R.A.; Peng, Y.; Norris, Z.A.; Tholey, R.M.; Talbott, V.A.; Liang, Q.; Ai, Y.; Miller, K.; Lal, S.; Cozzitorto, J.A.; et al. Mitoxantrone targets human ubiquitin-specific peptidase 11 (USP11) and is a potent inhibitor of pancreatic cancer cell survival. Mol. Cancer Res. MCR 2013, 11, 901-911. [CrossRef] [PubMed]

149. DepMap Achilles 18Q3 Public. Figshare. Available online: https://figshare.com/articles/dataset/DepMap_Achilles_18Q3 _public/6931364/1 (accessed on 3 August 2018).

150. Meyers, R.M.; Bryan, J.G.; McFarland, J.M.; Weir, B.A.; Sizemore, A.E.; Xu, H.; Dharia, N.V.; Montgomery, P.G.; Cowley, G.S.; Pantel, S.; et al. Computational correction of copy number effect improves specificity of CRISPR-Cas9 essentiality screens in cancer cells. Nat. Genet. 2017, 49, 1779-1784. [CrossRef]

151. Dempster, J.M.; Boyle, I.; Vazquez, F.; Root, D.; Boehm, J.S.; Hahn, W.C.; Tsherniak, A.; McFarland, J.M. Chronos: A CRISPR Cell Population Dynamics Model. bioRxiv 2021. [CrossRef]

152. Dharia, N.V.; Kugener, G.; Guenther, L.M.; Malone, C.F.; Durbin, A.D.; Hong, A.L.; Howard, T.P.; Bandopadhayay, P.; Wechsler, C.S.; Fung, I.; et al. A First-Generation Pediatric Cancer Dependency Map. Nat. Genet. 2021, 53, 529-538. [CrossRef]

153. Zhu, S.; Zhang, X.; Weichert-Leahey, N.; Dong, Z.; Zhang, C.; Lopez, G.; Tao, T.; He, S.; Wood, A.C.; Oldridge, D.; et al. LMO1 Synergizes with MYCN to Promote Neuroblastoma Initiation and Metastasis. Cancer Cell 2017, 32, 310-323.e5. [CrossRef]

154. Loontiens, S.; Depestel, L.; Vanhauwaert, S.; Dewyn, G.; Gistelinck, C.; Verboom, K.; Van Loocke, W.; Matthijssens, F.; Willaert, A.; Vandesompele, J.; et al. Purification of high-quality RNA from a small number of fluorescence activated cell sorted zebrafish cells for RNA sequencing purposes. BMC Genom. 2019, 20, 228. [CrossRef]

155. Olsen, R.R.; Otero, J.H.; García-López, J.; Wallace, K.; Finkelstein, D.; Rehg, J.E.; Yin, Z.; Wang, Y.-D.; Freeman, K.W. MYCN induces neuroblastoma in primary neural crest cells. Oncogene 2017, 36, 5075-5082. [CrossRef]

156. García-López, J.; Wallace, K.; Otero, J.H.; Olsen, R.; Wang, Y.-D.; Finkelstein, D.; Gudenas, B.L.; Rehg, J.E.; Northcott, P.; Davidoff, A.M.; et al. Large 1p36 Deletions Affecting Arid1a Locus Facilitate Mycn-Driven Oncogenesis in Neuroblastoma. Cell Rep. 2020, 30, 454-464.e5. [CrossRef] [PubMed]

157. Sausen, M.; Leary, R.J.; Jones, S.; Wu, J.; Reynolds, C.P.; Liu, X.; Blackford, A.; Parmigiani, G.; Diaz, L.A.; Papadopoulos, N.; et al. Integrated genomic analyses identify ARID1A and ARID1B alterations in the childhood cancer neuroblastoma. Nat. Genet. 2013, 45, 12-17. [CrossRef] [PubMed]

158. Cohen, M.A.; Zhang, S.; Sengupta, S.; Ma, H.; Bell, G.W.; Horton, B.; Sharma, B.; George, R.E.; Spranger, S.; Jaenisch, R. Formation of Human Neuroblastoma in Mouse-Human Neural Crest Chimeras. Cell Stem Cell 2020, 26, 579-592.e6. [CrossRef] [PubMed]

159. Mus, L.M.; Van Haver, S.; Popovic, M.; Trypsteen, W.; Lefever, S.; Zeltner, N.; Ogando, Y.; Jacobs, E.Z.; Denecker, G.; Sanders, E.; et al. Recurrent chromosomal imbalances provide selective advantage to human embryonic stem cells under enhanced replicative stress conditions. Genes. Chromosomes Cancer 2021, 60, 272-281. [CrossRef]

160. Akavia, U.D.; Litvin, O.; Kim, J.; Sanchez-Garcia, F.; Kotliar, D.; Causton, H.C.; Pochanard, P.; Mozes, E.; Garraway, L.A.; Pe'er, D. An integrated approach to uncover drivers of cancer. Cell 2010, 143, 1005-1017. [CrossRef]

161. Bonnet, E.; Calzone, L.; Michoel, T. Integrative Multi-omics Module Network Inference with Lemon-Tree. PLoS Comput. Biol. 2015, 11, e1003983. [CrossRef]

162. Champion, M.; Brennan, K.; Croonenborghs, T.; Gentles, A.J.; Pochet, N.; Gevaert, O. Module Analysis Captures Pancancer Genetically and Epigenetically Deregulated Cancer Driver Genes for Smoking and Antiviral Response. EBioMedicine 2018, 27, 156-166. [CrossRef]

163. Bhattacharya, A.; Bense, R.D.; Urzúa-Traslaviña, C.G.; de Vries, E.G.E.; van Vugt, M.A.T.M.; Fehrmann, R.S.N. Transcriptional effects of copy number alterations in a large set of human cancers. Nat. Commun. 2020, 11, 715. [CrossRef] [PubMed]

164. Boyle, E.A.; Li, Y.I.; Pritchard, J.K. An Expanded View of Complex Traits: From Polygenic to Omnigenic. Cell 2017, 169, 1177-1186. [CrossRef]

165. Alvarez, M.J.; Shen, Y.; Giorgi, F.M.; Lachmann, A.; Ding, B.B.; Ye, B.H.; Califano, A. Functional characterization of somatic mutations in cancer using network-based inference of protein activity. Nat. Genet. 2016, 48, 838-847. [CrossRef] [PubMed]

166. Min, L.; Zhang, C.; Qu, L.; Huang, J.; Jiang, L.; Liu, J.; Pinello, L.; Yuan, G.-C.; Shou, C. Gene regulatory pattern analysis reveals essential role of core transcriptional factors' activation in triple-negative breast cancer. Oncotarget 2017, 8, 21938-21953. [CrossRef] [PubMed]

167. Nicolle, R.; Radvanyi, F.; Elati, M. CoRegNet: Reconstruction and integrated analysis of co-regulatory networks. Bioinformatics 2015, 31, 3066-3068. [CrossRef] [PubMed] 
168. Paull, E.O.; Aytes, A.; Jones, S.J.; Subramaniam, P.S.; Giorgi, F.M.; Douglass, E.F.; Tagore, S.; Chu, B.; Vasciaveo, A.; Zheng, S.; et al. A modular master regulator landscape controls cancer transcriptional identity. Cell 2021, 184, 334-351.e20. [CrossRef]

169. Silverbush, D.; Cristea, S.; Yanovich-Arad, G.; Geiger, T.; Beerenwinkel, N.; Sharan, R. Simultaneous Integration of Multi-omics Data Improves the Identification of Cancer Driver Modules. Cell Syst. 2019, 8, 456-466.e5. [CrossRef]

170. Colaprico, A.; Olsen, C.; Bailey, M.H.; Odom, G.J.; Terkelsen, T.; Silva, T.C.; Olsen, A.V.; Cantini, L.; Zinovyev, A.; Barillot, E.; et al. Interpreting pathways to discover cancer driver genes with Moonlight. Nat. Commun. 2020, 11, 69. [CrossRef]

171. Rajbhandari, P.; Lopez, G.; Capdevila, C.; Salvatori, B.; Yu, J.; Rodriguez-Barrueco, R.; Martinez, D.; Yarmarkovich, M.; WeichertLeahey, N.; Abraham, B.J.; et al. Cross-Cohort Analysis Identifies a TEAD4-MYCN Positive Feedback Loop as the Core Regulatory Element of High-Risk Neuroblastoma. Cancer Discov. 2018, 8, 582-599. [CrossRef]

172. Yang, L.; Li, Y.; Wei, Z.; Chang, X. Coexpression network analysis identifies transcriptional modules associated with genomic alterations in neuroblastoma. Biochim. Biophys. Acta BBA-Mol. Basis Dis. 2018, 1864, 2341-2348. [CrossRef]

173. Zhang, L.; Lv, C.; Jin, Y.; Cheng, G.; Fu, Y.; Yuan, D.; Tao, Y.; Guo, Y.; Ni, X.; Shi, T. Deep Learning-Based Multi-Omics Data Integration Reveals Two Prognostic Subtypes in High-Risk Neuroblastoma. Front. Genet. 2018, 9, 477. [CrossRef]

174. Williams, R.M.; Candido-Ferreira, I.; Repapi, E.; Gavriouchkina, D.; Senanayake, U.; Ling, I.T.C.; Telenius, J.; Taylor, S.; Hughes, J.; Sauka-Spengler, T. Reconstruction of the Global Neural Crest Gene Regulatory Network In Vivo. Dev. Cell 2019, 51, 255-276.e7. [CrossRef]

175. Leo, L.; Colonna Romano, N. Emerging Single-Cell Technological Approaches to Investigate Chromatin Dynamics and Centromere Regulation in Human Health and Disease. Int. J. Mol. Sci. 2021, 22, 8809. [CrossRef] [PubMed]

176. Das, S.; Camphausen, K.; Shankavaram, U. Pan-Cancer Analysis of Potential Synthetic Lethal Drug Targets Specific to Alterations in DNA Damage Response. Front. Oncol. 2019, 9, 1136. [CrossRef] [PubMed]

177. Mullard, A. Targeted protein degraders crowd into the clinic. Nat. Rev. Drug Discov. 2021, 20, 247-250. [CrossRef] [PubMed] 